\title{
Petrology and geochemistry of the Tertiary alkaline intrusive rocks at Doupov, Doupovské hory Volcanic Complex (NW Bohemian Massif)
}

\author{
František V. HOLUB ${ }^{1, *}$, Vladislav RAPPRICH², Vojtěch ERBAN², Zoltán PÉCSKAY , Bedřich \\ MLČOCH², Jitka MíKOVÁ2
}

${ }^{1}$ Institute of Petrology and Structural Geology, Faculty of Science, Charles University in Prague, Albertov 6, 12843 Prague 2, Czech Republic; frholub@natur.cuni.cz

${ }^{2}$ Czech Geological Survey, Klárov 3, 11821 Prague 1, Czech Republic

${ }^{3}$ Institute of Nuclear Research, Hungarian Academy of Sciences, Bem tér 18/C, H-4001 Debrecen, Hungary

${ }^{*}$ Corresponding author

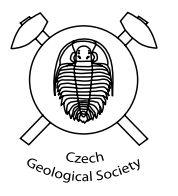

Field observations, petrography, geochemical data and the results of K-Ar dating are presented for Oligocene (c. 30-29 Ma) alkaline intrusions at the former township of Doupov (Duppau) in the central part of the Doupovske hory Volcanic Complex (DHVC).

The Doupov Intrusive Complex (DIC) is a very limited in area $\left(<2 \mathrm{~km}^{2}\right)$ but is petrographically highly variable. Several phaneritic rock types have been identified, including clinopyroxenite (both the clinopyroxenite-dominated breccia and xenoliths in younger intrusive phases), essexite, sodalite-bearing monzodiorite, sodalite monzosyenite to nepheline-sodalite syenite, and highly mafic to felsic nephelinolites (melteigite-ijolite-urtite). These rocks are accompanied by vent breccias, and a thermal and metasomatic aureole with zones of pervasive phlogopitization. Phaneritic intrusions and their host rocks are cut by thin aphanitic dykes ranging from mafic alkaline lamprophyres to felsic trachytes and phonolites. All the intrusions are characterized by undersaturated alkaline compositions with high abundances of incompatible elements.

Geochemical variations and also subtle differences in the isotopic compositions of $\mathrm{Sr}$ and $\mathrm{Nd}$ suggest that the less undersaturated essexitic rocks and sodalite syenitoids do not form a common evolutionary line with highly undersaturated nephelinolites. Nephelinolites are isotopically close to the "European Asthenospheric Reservoir" or the "Common Mantle Reservoir" compositions and interaction of their parental magmas with the continental crust was negligible. Magmatic evolution of nephelinolites with "dry" mineral assemblages was dominated by fractionation of clinopyroxene accompanied at the early stage by olivine, and later by titanite, magnetite and apatite. Essexite is isotopically more different though still within the field of mafic lavas from DHVC and other volcanic complexes in Central and Western Europe. Either its parental magma originated in heterogeneous mantle with more distinct lithospheric signature or this magma reacted with the continental crust during its ascent and fractionation. Sodalite monzosyenite displays significantly higher ${ }^{87} \mathrm{Sr} /{ }^{86} \mathrm{Sr}$ ratios and its parental magma probably interacted even more intensively with the crustal rocks. The K-Ar ages of phaneritic intrusive rocks from Doupov are c. 30-29 Ma. Intrusions are older than the tephrite-basanite and foidite lavas forming the upper parts of the DHVC.

The rock association resembles that accompanying many carbonatite intrusions around the world. However, brecciation and high-temperature metasomatic overprint including the extensive phlogopitization may be related to ijolitic magma. Nevertheless, the presence of carbonatite at some deeper level cannot be excluded.

Keywords: alkaline rocks, nephelinolite, petrology, geochemistry, Ohře Graben, Bohemian Massif Received: 24 June 2010; accepted: 15 September 2010; handling editor: E. Jelinek

The online version of this article (doi: 10.3190/jgeosci.074) contains supplementary electronic material.

\section{Introduction}

Many alkaline volcanic complexes around the world are accompanied by phaneritic intrusive members, some of them also with carbonatites. Such intrusions of plutonic appearance are rather rare within the volcanic complexes associated with the European Cenozoic Rift System. These were described namely from the Kaiserstuhl situ- ated within the S part of the Rhine Graben (Germany), where ultramafic to felsic highly undersaturated intrusive rocks are accompanied by both intrusive and volcanic carbonatites (Wimmenauer 1974; Keller 1981).

The Bohemian Massif contains two large volcanic complexes including subvolcanic intrusions - the larger České středohoří Volcanic Complex in the NE part and the less voluminous Doupovské hory Volcanic Complex 


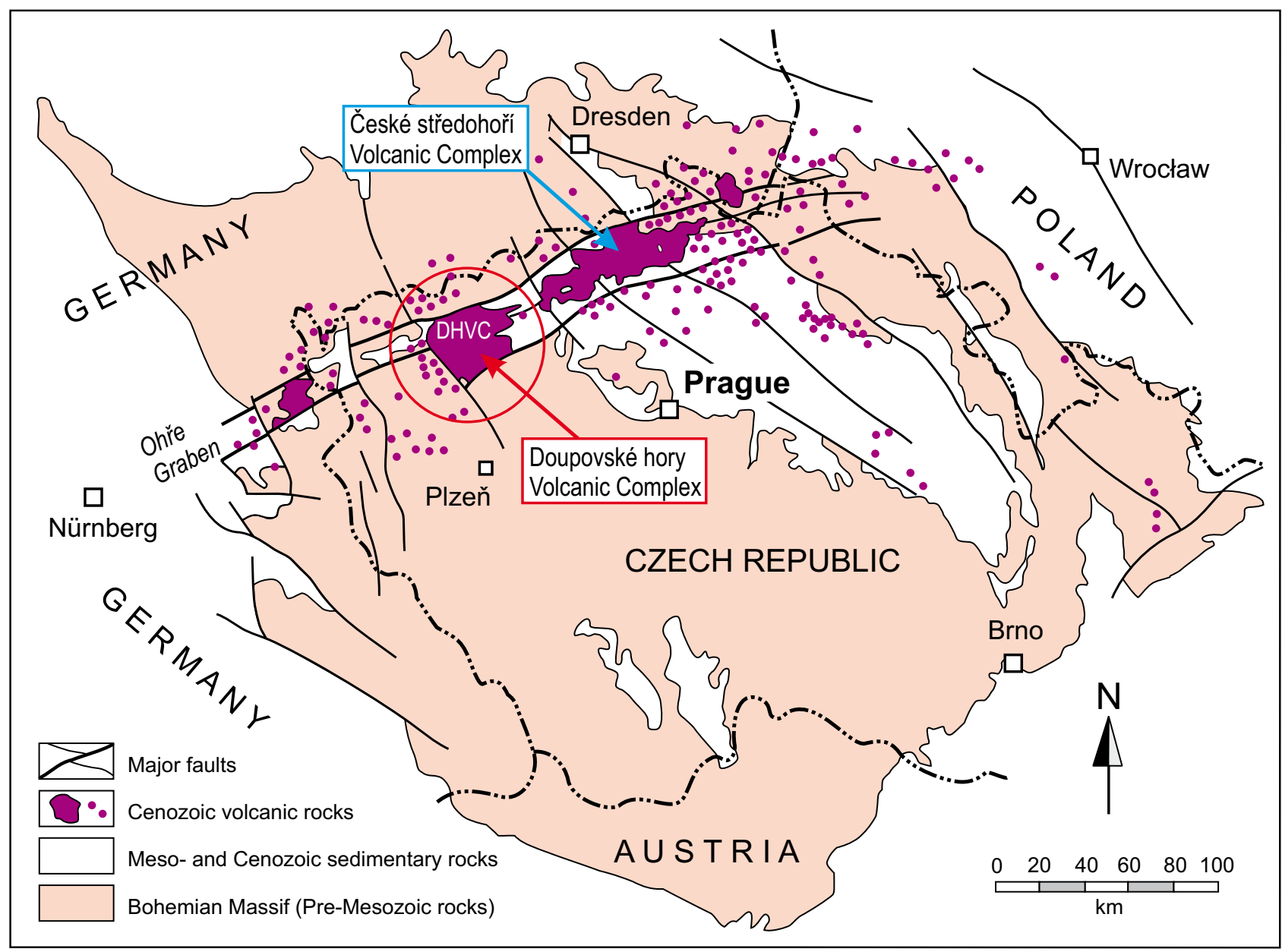

Fig. 1 Geological sketch of the Bohemian Massif showing the Ohře Graben, outlines of major Cenozoic volcanic complexes therein, and schematic position of significant scattered localities of the Cenozoic volcanism (small circles).

(DHVC) in the south-western part of the Ohře (Eger) Graben (Fig. 1). Present paper is focused on the DHVC whose intrusive members are still poorly known. These rocks crop out at the locality called Flurbühl (or Flurhübl in some older papers), a small hill (648.5 m above sea level) located in the close SW vicinity of the former small town of Doupov (Duppau). The locality is situated in the central part of the DHVC (Fig. 2) in the middle of a large military training area.

This paper presents the most important data on the petrography, whole-rock major- and trace-element geochemistry and a limited number of $\mathrm{Sr}$ and $\mathrm{Nd}$ isotopic analyses for alkaline intrusive rocks of the Doupov Intrusive Complex. New K-Ar ages were also determined for selected samples. Additional data including mineral analyses are given in the Supplementary electronic material (Supplements S1 to S8). A more detailed study focusing on the mineralogical development of ijolitic rocks can be found in Haloda et al. (this volume).

\section{Geological setting}

\subsection{Doupovské hory Volcanic Complex}

The NE branch of the European Cenozoic Rift System (ECRIS, Dèzes et al. 2004) is formed by the Ohře (Eger) Graben. It runs across the western part of the Bohemian Massif in the ENE-WSW direction (Fig. 1), roughly following the Variscan suture between the Saxothuringian and Teplá-Barrandian domains of the Bohemian Massif (see Mlčoch and Konopásek 2010).

In the south-western part of the Ohře (Eger) Graben is situated the Doupovské hory Volcanic Complex (DHVC) covering an area of nearly $600 \mathrm{~km}^{2}$. Several geological units join in the basement of the DHVC in the form of a heterogeneous crustal mosaic. The Saxothuringian Unit (paragneisses, felsic granulites, orthogneisses, mica schists, and phyllites) extends in the basement of the DHVC from the north as far as to the Střezov and Petrov 


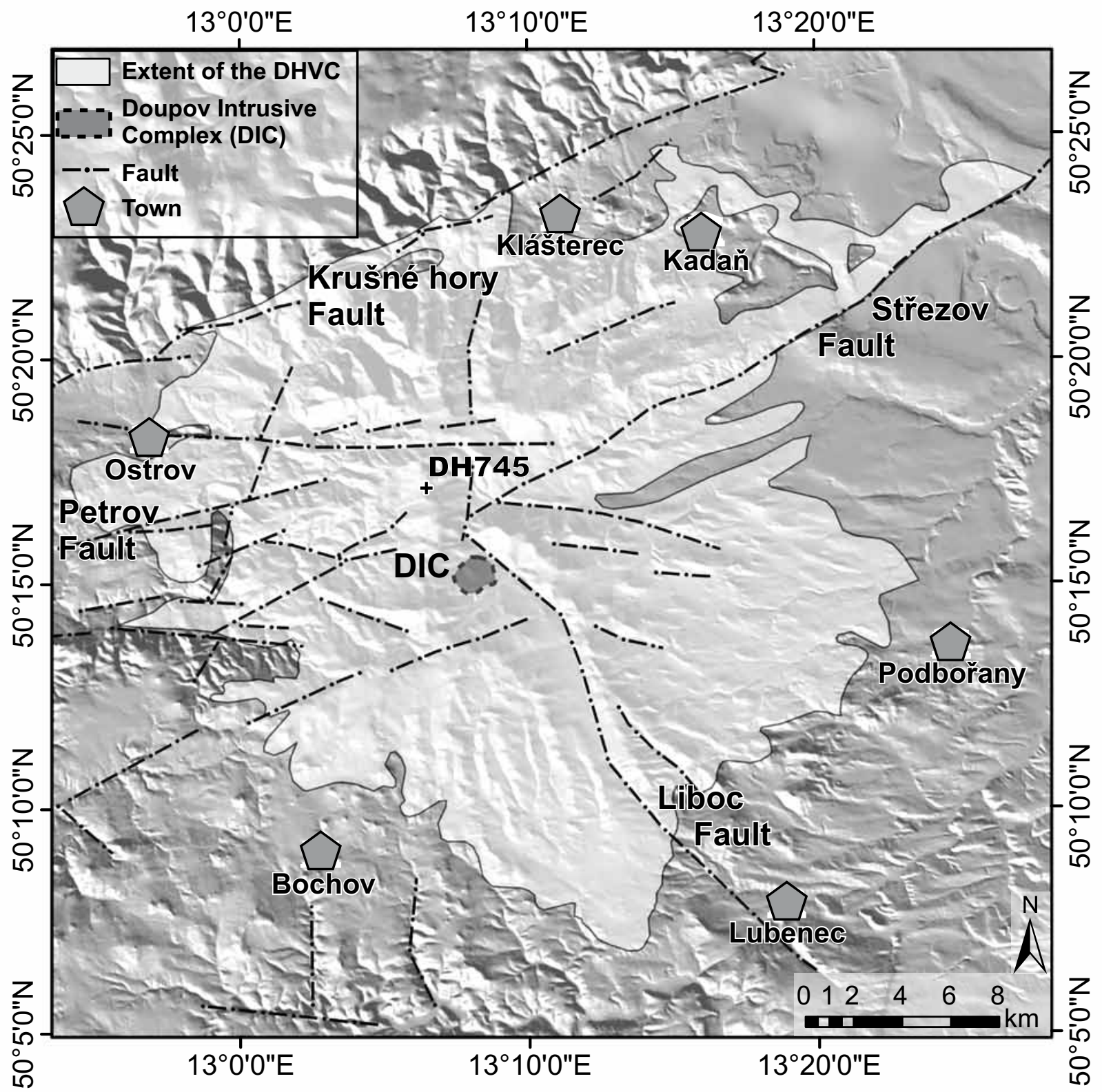

Fig. 2 Position of the Doupov Intrusive Complex (DIC) within the Doupovské hory Volcanic Complex (DHVC) with the regional fault pattern. Location of the sample DH745 (haüyne-phyric phonolite dyke) is shown NW of the DIC.

faults (Fig. 2). Variscan granites (Nejdek-Eibenstock Pluton) plunge beneath the DHVC from the west. Metamorphic rocks of the Teplá-Barrandian Unit (garnet-kyanite gneisses, micaschists and phyllites) form the fundament to the south. Metamorphosed basic and ultrabasic rocks (amphibolites, eclogites, and peridotites to serpentinites, equivalent to the Mariánské Lázně Complex - Mlčoch and Konopásek 2010) occur beneath the central part of the DHVC (Mlčoch 2003, 2006). The south-eastern sector of the DHVC (delimited by the Střezov and Liboc faults - Fig. 2) is underlain by a thick sequence of Late-
Palaeozoic sedimentary rocks covering the Teplá-Barrandian Unit basement.

Formation of the DHVC started during the Lowermost Oligocene (mammal zone MP-21: Fejfar and Kaiser 2005) and lasted up to the Lower Miocene. The complex consists of alkaline volcanic rocks, namely foidites, basanites and tephrites. Weak erosion preserved superficial products dominated by sequences of mafic lavas with subordinate concomitant volcaniclastics, whereas the subvolcanic systems mostly remained hidden. 
The DHVC was formerly interpreted as a huge stratovolcano (e.g., Zartner 1938; Šantrůček et al. 1967; Kopecký 1987-88). However, voluminous pyroclastic material was produced only during the early stages of volcanic evolution (Hradecký 1997). Subsequent, almost purely effusive activity from a number of local vents (e.g., Hradecký 1997; Cajz et al. 2006) and sequences of gently dipping lava flows forming the upper parts of the DHVC (e.g., Rapprich and Holub 2008), indicate a cluster of shield volcanoes rather than a single stratovolcano.

\subsection{Doupov Intrusive Complex}

The occurrence of relatively coarse-grained, subvolcanic intrusive rocks originally referred to as theralites in the close south-western vicinity of Doupov has been known since the beginning of the $20^{\text {th }}$ century (Becke 1900; Wiesbaur 1901; Bauer 1903). For a long time, these intrusions were considered to mark the position of a major stratovolcano conduit or "volcanic centre" within the "central crater" or caldera (e.g., Šantrůček et al. 1967; Kopecký 1988).

Kopecký (1988) briefly described the major intrusion at Doupov as a vertical stock $450 \times 100 \mathrm{~m}$ in a NW-SE elongated outcrop, which is composed largely of essexite, locally grading to theralite. This stock is surrounded by pyroxenite and pyroxenite breccia built by partially phlogopitized augite and penetrated by small dykes of nepheline to sodalite syenite. Another variety of pyroxenite has been characterized as jacupirangite dominated by clinopyroxene and also containing about $30 \%$ nepheline, opaque minerals and an accessory amount of garnet. Kopecký (1988) estimated the total outcrop area of the complex including marginal pyroxenites to be c. $1300 \times 300 \mathrm{~m}$.

The whole composite intrusion is called the Doupov Intrusive Complex (DIC) in this paper. Its size is definitely larger and the distribution of the various rock types appears much less regular compared to Kopecký's description. We have found rocks assigned to, or believed to be genetically linked with, the DIC at and around the Flurbühl Hill within an area of $c .1500 \times 1200 \mathrm{~m}$.

Contacts of the intrusive rocks are not exposed. Weathered vent or diatreme breccia containing phlogopite megacrysts occurs adjacent to the eastern border of phaneritic intrusive rocks and perhaps represents the immediate host rock of intrusions. This breccia brought abundant amphibolite xenoliths, originally interpreted as an outcrop of basement rocks (Zartner 1938). Fine-grained breccia is present secondarily in the DP-3 borehole located close to the NW border of DIC. Breccia-looking but otherwise massive rocks are present also in the roof of phaneritic intrusions. These observations imply the possibility that massive intrusions were emplaced into a pre-existing diatreme.

The coordinates of the sampling sites and their location within proposed outline of the DIC are given in Supplements S1 and S2. Sampling sites including two drillings (DB-2 and DP-3) from 1968 are commented in Supplement S3.

\section{Analytical methods}

\subsection{Mineral chemistry}

The composition of the anhydrous rock-forming minerals was studied using the CamScan 3400 electron microprobe (Czech Geological Survey, Prague) at an operation current of 2.5-3 nA, voltage of $15 \mathrm{kV}$ and $100 \mathrm{~s}$ counting time. An Energy Dispersive System (EDS - Link ISIS 300) was employed to acquire quantitative analyses. The foid minerals were analysed by a defocused beam to omit alkali loss during the analyses. The advantage of real-time control on running EDS analyses was crucial for study of the feldspathoid composition, as the stability of the alkali signal could have been controlled simultaneously with the analysis.

The (OH, F)-bearing minerals (micas and amphiboles) were analysed largely using the Cameca SX 100 wavelength-dispersive electron microprobe at the Geological Institute, Academy of Sciences of the Czech Republic. The operation current was $10 \mathrm{nA}$ and the voltage $15 \mathrm{kV}$. The diameter of the focused beam varied from 1 to $2 \mu \mathrm{m}$.

Selected mineral analyses are tabulated in the supplementary electronic material.

\subsection{Whole-rock geochemistry}

Samples were analysed for major- and trace-element contents in the Activation Laboratories, Ltd. (Ancaster, Ontario). Prior to the analysis, the samples were mixed with a lithium metaborate and lithium tetraborate flux and fused in an induction furnace. The melt was poured into a solution of $5 \%$ nitric acid containing an internal standard, and mixed continuously until completely dissolved. The samples were run for major oxides and Sc, $\mathrm{Sr}, \mathrm{Ba}, \mathrm{V}$ on a combination simultaneous/sequential Thermo Jarrell-Ash ENVIRO II ICP-OES or a Spectro Ciros ICP-OES; all the remaining trace elements including REE were determined using the Perkin Elmer SCIEX ELAN 6000 or 6100 ICP-MS. The estimated analytical uncertainties for concentrations of $<100$ ppm vary from element to element but are commonly better than $\pm 10 \%$. Detailed tables of control analyses of reference 
materials together with certified values are available as supplementary electronic material.

Moreover, selected samples were also analyzed for major elements by wet chemistry in the laboratories of the Czech Geological Survey (Prague Barrandov). When available, these wet analyses are preferred.

Whole-rock analytical data were processed using the Geochemical Data Toolkit (GCDkit) (Janoušek et al. 2006).

\section{3. $\mathrm{Sr}-\mathrm{Nd}$ isotopes}

Selected samples were analysed for the $\mathrm{Sr}$ and $\mathrm{Nd}$ isotopic compositions in the laboratories of the Czech Geological Survey in Prague. Each sample was dissolved by combined $\mathrm{HF}-\mathrm{HCl}-\mathrm{HNO}_{3}$ decomposition. Strontium was isolated by ion exchange chromatography using the Sr.spec Eichrom resin, neodymium with TRU.spec and Ln.spec Eichrom resins (see Míková and Denková 2007 for details). Isotopic analyses of $\mathrm{Sr}$ and $\mathrm{Nd}$ were performed on a Finnigan MAT 262 Thermal Ionization Mass Spectrometer in a dynamic mode using single and double Re filament assemblies, respectively. The $\mathrm{Sr}$ and $\mathrm{Nd}$ ratios were corrected for mass fractionation assuming ${ }^{146} \mathrm{Nd} /{ }^{144} \mathrm{Nd}=0.7219$ and ${ }^{86} \mathrm{Sr} /{ }^{88} \mathrm{Sr}=0.1194$. The precision and external reproducibility are demonstrated by repeated analyses of the La Jolla $\left[{ }^{143} \mathrm{Nd} /{ }^{144} \mathrm{Nd}\right.$ $=0.511852 \pm 14(2 \sigma ; \mathrm{n}=23)]$ and NBS $987\left[{ }^{87} \mathrm{Sr} /{ }^{86} \mathrm{Sr}\right.$ $=0.710247 \pm 26(2 \sigma ; \mathrm{n}=25)]$ isotopic reference materials.

\subsection{K-Ar dating}

Three selected whole-rock samples and two samples of separated phlogopite were dated using the potassium-argon method. The geochronological analyses were performed in the ATOMKI Laboratories, Debrecen, Hungary. After acid digestion and $0.2 \mathrm{M} \mathrm{HCl}$ dissolution of the samples, the potassium content was determined by flame photometry with a $\mathrm{Na}$ buffer and $\mathrm{Li}$ internal standard. Measurements were checked by inter-laboratory standards (Asia 1/65, LP-6, HD-B1 and GL-O). Argon was extracted from the samples by radiofrequency fusion in Mo crucibles under vacuum conditions. A ${ }^{38} \mathrm{Ar}$-spike was added to samples prior to gas-cleaning in $\mathrm{Ti}$ and SAES getters and liquid nitrogen traps, respectively. The isotope ratios of argon were measured in the static mode using a $15 \mathrm{~cm}$ radius magnetic sector-type mass spectrometer in Debrecen. Balogh (1985) and Odin (1982) described the methods employed in detail. Age calculations were based on constants proposed by Steiger and Jäger (1977). Results of $\mathrm{K}-\mathrm{Ar}$ dating are given with $1 \sigma$ errors.

\section{Petrographic types}

\subsection{Overview of the petrographic variability}

Within the limits of the DIC, we have found vent or diatreme breccias with phlogopite megacrysts and basement xenoliths, heterogeneous breccias cemented by a fine-grained rock resembling dense basanitic lava (Fig. $3 \mathrm{a}-\mathrm{b})$, clinopyroxenite breccias infiltrated by syenitic veinlets (Fig. 3c), variable mafic to felsic nephelinolites, essexites, foid monzodiorite and foid monzosyenite dykes with variable mafic to clinopyroxene-dominated ultramafic xenoliths (Fig. 3d-e). Moreover, these breccias and phaneritic intrusive rocks are crosscut by thin aphanitic dykes with lamprophyric and trachytic to phonolitic compositions (Fig. 3f). Similar dykes also occur in the surrounding lavas.

Phaneritic intrusive rocks consist of various combinations and proportions of clinopyroxene (diopside), hornblende (kaersutite to pargasite), biotite (phlogopite to magnesian biotite) and olivine as mafic minerals. Nepheline, sodalite sensu lato (including nosean, haüyne), plagioclase and K-feldspar (sanidine) are the main felsic minerals. Typical accessory minerals are magnetite, ilmenite, titanite and apatite. Limited amounts of epidote, pyrite, analcime, calcite, and zeolite minerals may be present as alteration products of post-magmatic origin. However, most samples are practically devoid of lowtemperature minerals.

Magmatic mineral assemblages are both "dry" (lacking significant amounts of hydrous mafic minerals like hornblende) and "wet" (involving abundant hornblende and/or biotite). Typical mineral assemblages of the individual rock types are presented in Tab. 1. Modal analyses of representative samples are given in Tab. 2. Microprobe analyses of main groups of mafic rock-forming minerals (clinopyroxene, hornblende and biotite) can be found in the Supplementary electronic material (Supplements S4-6).

\subsection{Nephelinolites (melteigite-ijolite-urtite)}

Nephelinolites were found as loose blocks in the eastern and western marginal parts of the complex. They are absent both around the summit of the Flurbühl Hill and in the DB-2 borehole. The colour indices of nephelinolites are highly variable, enabling us to distinguish olivinebearing melteigite (melanocratic variety, probably referred to as jacupirangite by Kopecký 1988), ijolite and, finally, urtite with less than 30 vol. \% of mafic minerals (see Le Maitre et al. 2002). Leucocratic rock classified as urtite (leucocratic nephelinolite) has been found only as a small loose block (sample DR051B). Nephelinolites 

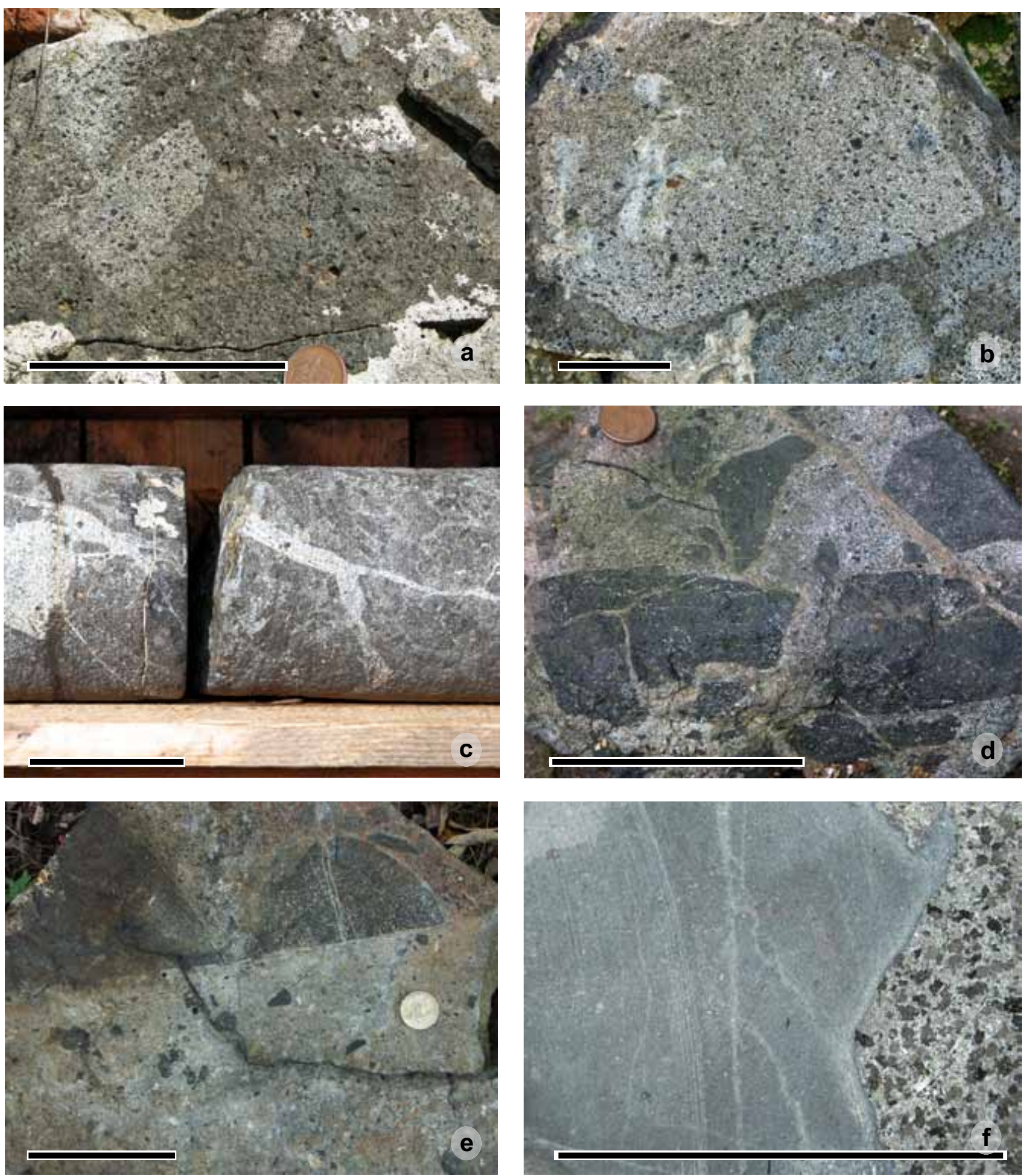

Fig. 3 Field photos of studied rocks. a-b - Vent (?) breccia from the roof of the DIC (wall of a wayside shrine on the top of the Flurbühl Hill); c - Clinopyroxenite breccia intruded by thin veinlets of sodalite syenite (drill core DB-2); d - Essexite-sodalite monzosyenite intrusive breccia; $\mathbf{e}$ - Essexite-dominated intrusive breccia crosscut by a dyke of sodalite monzosyenite; $\mathbf{f}$ - Hornblende-rich essexite intruded by aphanitic trachyte to phonolite (drill core DB-2). Bar is $10 \mathrm{~cm}$, coin $2.5 \mathrm{~cm}$ in diameter. 
Tab. 1 Mineral assemblages of phaneritic intrusive rocks from the Doupov Intrusive Complex

\begin{tabular}{|c|c|c|c|c|c|c|c|c|}
\hline & C.I. & Olivine & Cpx & $\mathrm{Hbl}$ & $\mathrm{Bt}$ & Foids & $\mathrm{Kfs}$ & Plg \\
\hline Clinopyroxenite & $90-100$ & ० & $\bullet \bullet \bullet \bullet$ & ০/• & 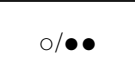 & $\begin{array}{c}/ / \\
\mathrm{Sdl}\end{array}$ & $/ /$ & $\circ$ \\
\hline Melteigite & $>70$ & $\stackrel{\bullet}{\mathrm{Fo}_{85-72}}$ & $\begin{array}{c}\bullet \bullet \bullet \\
\mathrm{mg} 84-74\end{array}$ & $\begin{array}{c}\circ / \cdot \\
(\mathrm{mg} \mathrm{58)}\end{array}$ & $\begin{array}{c}\text { o/• } \\
\text { mg 58-90 }\end{array}$ & $\stackrel{\bullet \bullet}{\mathrm{Ne}}$ & $\bullet$ & $\circ$ \\
\hline Ijolite & $50-70$ & $\begin{array}{c}\circ / \bullet \\
\mathrm{Fo}_{85-83}\end{array}$ & $\stackrel{\bullet \bullet \bullet \bullet}{\operatorname{mg} 85-71}$ & $\operatorname{mg} \stackrel{\circ / \cdot}{50-57}$ & 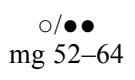 & Ne (Sdl) & $\bullet$ & ○ \\
\hline Urtite & $<30$ & $\circ$ & mg $\stackrel{\bullet}{57-78}$ & ○ & mg 57-82 & $\stackrel{\bullet \bullet \bullet}{\mathrm{Ne}>\mathrm{Sdl}}$ & $\bullet \bullet$ & ○ \\
\hline Essexite & $40-70$ & $(\bullet) / \circ$ & mg $81-64$ & mg 38-62 & $\mathrm{mg}$ 45-52 & $\stackrel{\bullet}{\mathrm{Ne}}$ & $\bullet$ & $\stackrel{\bullet \bullet}{\mathrm{An}_{5444}}$ \\
\hline Monzodiorite & $30-40$ & ○ & $\bullet \bullet$ & - & $\bullet \bullet$ & $\stackrel{\bullet}{\mathrm{Sd} l}$ & $\bullet$ & $\bullet \bullet \bullet$ \\
\hline Sodalite monzonite & $25-35$ & ० & $\bullet \bullet$ & $\bullet$ & $\bullet \bullet$ & $\stackrel{\bullet}{\mathrm{Sdl}}$ & $\bullet \bullet$ & $\bullet \bullet$ \\
\hline Sodalite monzosyenite & $<25$ & ० & $\operatorname{mg} \stackrel{\bullet}{64-77}$ & $\operatorname{mg} \stackrel{\bullet}{42-60}$ & $\operatorname{mg~} \stackrel{\bullet}{56-70}$ & $\stackrel{\bullet}{\bullet \bullet}(\mathrm{Ne})$ & $\bullet \bullet \bullet$ & $\stackrel{\bullet \bullet}{\mathrm{An}_{<33}}$ \\
\hline
\end{tabular}

C.I. - Colour Index (vol. \% of mafic minerals); $\mathrm{mg}=100 \mathrm{Mg} /\left(\mathrm{Mg}+\mathrm{Fe}_{\text {tot }}\right)$

Symbols for presence and abundance of mineral constituents: $\circ-$ absent; $\bullet-$ may be present sporadically; $\bullet-$ present; $\bullet \bullet-$ present as typical

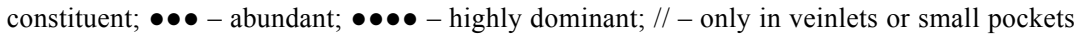

Abbreviations for minerals: Cpx - calcic clinopyroxene (diopside); Hbl - hornblende (kaersutite, pargasite); Bt - biotite; Kfs - K-feldspar; Plg plagioclase; Sdl - sodalite group mineral; $\mathrm{Ne}$ - nepheline

Tab. 2 Modal analyses (vol. \%) of selected phaneritic intrusive rocks from the Doupov Intrusive Complex

\begin{tabular}{|c|c|c|c|c|c|c|c|c|}
\hline & 1 & 2 & 3 & 4 & 5 & 6 & 7 & 8 \\
\hline Sample & DH1330 & DH1319 & DR052 & DR051B & TV52 & DB2 & TV54 & DB2 \\
\hline Rock & Melteigite & Ijolite & Mica ijolite & Urtite & Essexite & $\begin{array}{c}\text { Sodalite } \\
\text { monzodiorite }\end{array}$ & $\begin{array}{c}\text { Sodalite } \\
\text { monzosyenite }\end{array}$ & Clinopyroxenite \\
\hline Olivine & 4 & - & 3 & - & 2 & - & - & - \\
\hline Clinopyroxene & 63 & 58 & 46 & 15 & 29 & 23 & 5 & 79 \\
\hline Hornblende & trace & trace & - & trace & 18 & 2 & 7 & 1 \\
\hline Biotite & 1 & 3 & 12 & trace & 10 & 10 & 5 & 8 \\
\hline Plagioclase & - & - & - & - & 21 & 48 & 24 & - \\
\hline K-feldspar & 7 & 8 & 2 & 20 & 5 & 3 & 38 & 1 \\
\hline Nepheline & 18 & 24 & 25 & 44 & 3 & 1 & - & - \\
\hline Sodalite $s . l . *$ & - & - & 2 & 15 & - & 6 & 13 & 3 \\
\hline Analcime & - & - & - & - & 1 & trace & - & - \\
\hline Zeolites & - & - & - & - & 1 & - & - & - \\
\hline Titanite & 0.1 & + & 3 & 2 & 4 & 2 & 3 & - \\
\hline Magnetite & 5 & 4 & 4 & 2 & 4 & 3 & 2 & 5 \\
\hline Ilmenite & 1 & 1 & trace & trace & trace & trace & trace & trace \\
\hline Apatite & 0.9 & 1.5 & 3 & 2 & 2 & 2 & 2 & 3 \\
\hline Sum & 100 & 99.5 & 100 & 100 & 100 & 100 & 99 & 100 \\
\hline Colour index & 73 & 65 & 68 & 19 & 67 & 40 & 23 & 93 \\
\hline
\end{tabular}

* including its alteration products 
are plagioclase-free but contain K-feldspar and sodalite (Tab. 1). The absence of (OH, F)-bearing mafic minerals, namely amphiboles, is typical of most samples of these rocks.

\subsubsection{Olivine melteigite and ijolite}

Ijolitic rocks are mesocratic to melanocratic rocks dominated by subhedral to almost euhedral, purplish Ti-rich clinopyroxene (titanian diopside) with Ti-poor crystal cores (Fig. 4a). However, olivine with normal zoning $\left(\mathrm{Fo}_{85-73}\right)$ has been found in several samples. The main felsic mineral is relatively coarse but anhedral and interstitial K-bearing nepheline $\left(4.8-5.5\right.$ wt. $\left.\% \mathrm{~K}_{2} \mathrm{O}\right)$. Nepheline may be accompanied by subordinate sodalite, which is commonly altered. Magnetite, titanite, ilmenite and apatite are common accessory phases. Apatite forms abundant euhedral needles.

A variety of olivine-bearing ijolite with abundant phlogopite was found as a loose block in the westernmost part of the Doupov Intrusive Complex (sample DR052).

The clinopyroxenes from mafic phaneritic rocks (melteigite, ijolite and essexite) display similar features. The individual grains are compositionally and optically zoned. Their cores contain more magnesium and lower amounts of both $\mathrm{TiO}_{2}$ and $\mathrm{Al}_{2} \mathrm{O}_{3}$ compared to the surrounding oscillatory growth zones and crystal rims. The rims have slightly higher contents of $\mathrm{TiO}_{2}$ and $\mathrm{A}_{2} \mathrm{O}_{3}$ but lower $\mathrm{FeO}_{\text {tot }}, \mathrm{MgO}$ and $\mathrm{Cr}_{2} \mathrm{O}_{3}$ than the cores. Compositional variations of pyroxene and the problems associated with its classification were discussed by Rapprich (2005). He concluded that large crystals of clinopyroxene from essexite compositionally resemble phenocrysts in tephritic lavas and display the same evolutionary trend. The compositions of aluminian diopside in the cores and titanian aluminian subsilicic diopside in marginal parts of crystals are typical.

Amphiboles only rarely found in ijolite to melteigite correspond to kaersutite with 5.3-6.3 wt. \% $\mathrm{TiO}_{2}$.

\subsubsection{Urtite}

Urtite DR051B is a greyish-white rock macroscopically similar to fine-grained syenite. Felsic constituents are dominated by euhedral nepheline $(0.2-0.6 \mathrm{~mm}$; Fig. $4 \mathrm{~b})$, subordinate sodalite or yellowish products of its alteration, and interstitial K-feldspar. Clinopyroxene in small subhedral grains is variable in colour $(\mathrm{Z}$ - brown-violet to greenish) and corresponds to diopside with $\mathrm{Mg} / \mathrm{Mg}+$ $\mathrm{Fe}+\mathrm{Mn})=0.57-0.78$. Small grains included in euhedral nepheline are rich in $\mathrm{TiO}_{2}$ and $\mathrm{Al}_{2} \mathrm{O}_{3}$ (up to 9.3 and 5.8 wt. $\%$, respectively), whereas discrete grains in the matrix are poor in these oxides. Matrix diopside may be more magnesian, perhaps due to contemporary crystallization of magnetite. The contents of $\mathrm{Na}_{2} \mathrm{O}$ and the aegirine component are generally low (commonly less than 1.2 wt. $\%$ and $4.5 \mathrm{~mol} . \%$, respectively). Scarce mica (several small anhedral grains per thin section) corresponds to phlogopite with less magnesian cores $(\mathrm{Mg} / \mathrm{Fe}$ 1.3-1.5) and highly magnesian rims (2.9-4.7). This "inverse" type of zoning of both phlogopite and clinopyroxene reflects the increasing oxidation and co-precipitation of magnetite. Titanite, magnetite, and apatite ( $<1$ vol. \%) are accessory minerals.

\subsection{Essexites}

Essexitic rocks are common in limited outcrops $\mathrm{W}$ and $\mathrm{N}$ of the Flurbühl hill-top but very subordinate in the DB-2 borehole. Essexites display typically "wet" mafic mineral assemblage with abundant hornblende and great textural and mineralogical variability. Large amphibole crystals (Fig. 3f) are important for the appearance of relatively coarse varieties of the rock. Abundance of amphibole is the major criterion for distinguishing essexitic rocks from mafic nephelinolites in the field.

Most typical essexite samples are composed of clinopyroxene, amphibole, biotite (phlogopite to magnesian biotite) and various amounts of plagioclase (labradorite to andesine), K-feldspar and nepheline. Some varieties contain variously altered sodalite instead of nepheline; the presence of a limited amount of analcime is much less common. Magnetite, titanite and apatite are the most common accessory to minor constituents.

Clinopyroxene is subhedral to almost euhedral and strongly zoned with evolutionary trends similar to those in tephritic lavas (Rapprich 2005). The almost homogeneous crystal cores of diopside low in $\mathrm{TiO}_{2}$ are surrounded by oscillatory growth zones of titanian diopside with purplish colour (Fig. 4c). Hornblende (Fig. 4d) is commonly larger (up to $7 \mathrm{~mm}$ in some varieties) and constitutes individual poikilitic crystals as well as overgrowths on clinopyroxene. The predominant parts correspond to kaersutite and titanian pargasite. It is deep reddish brown along the $\mathrm{Z}$-direction, and there are marginal zones that are deeply brownish-green coloured. The filling of the spaces between the mafic phases is dominated by large, tabular to anhedral plagioclase, accompanied by irregularly distributed interstitial K-feldspar and nepheline.

Many essexite samples display irregular mineral distribution with patchy concentrations of minerals. In some thin sections (e.g., DI3), small (several $\mathrm{mm}$ in diameter) patches of ijolitic assemblage clinopyroxene + nepheline are present, surrounded by common "wet" assemblages rich in hornblende. 

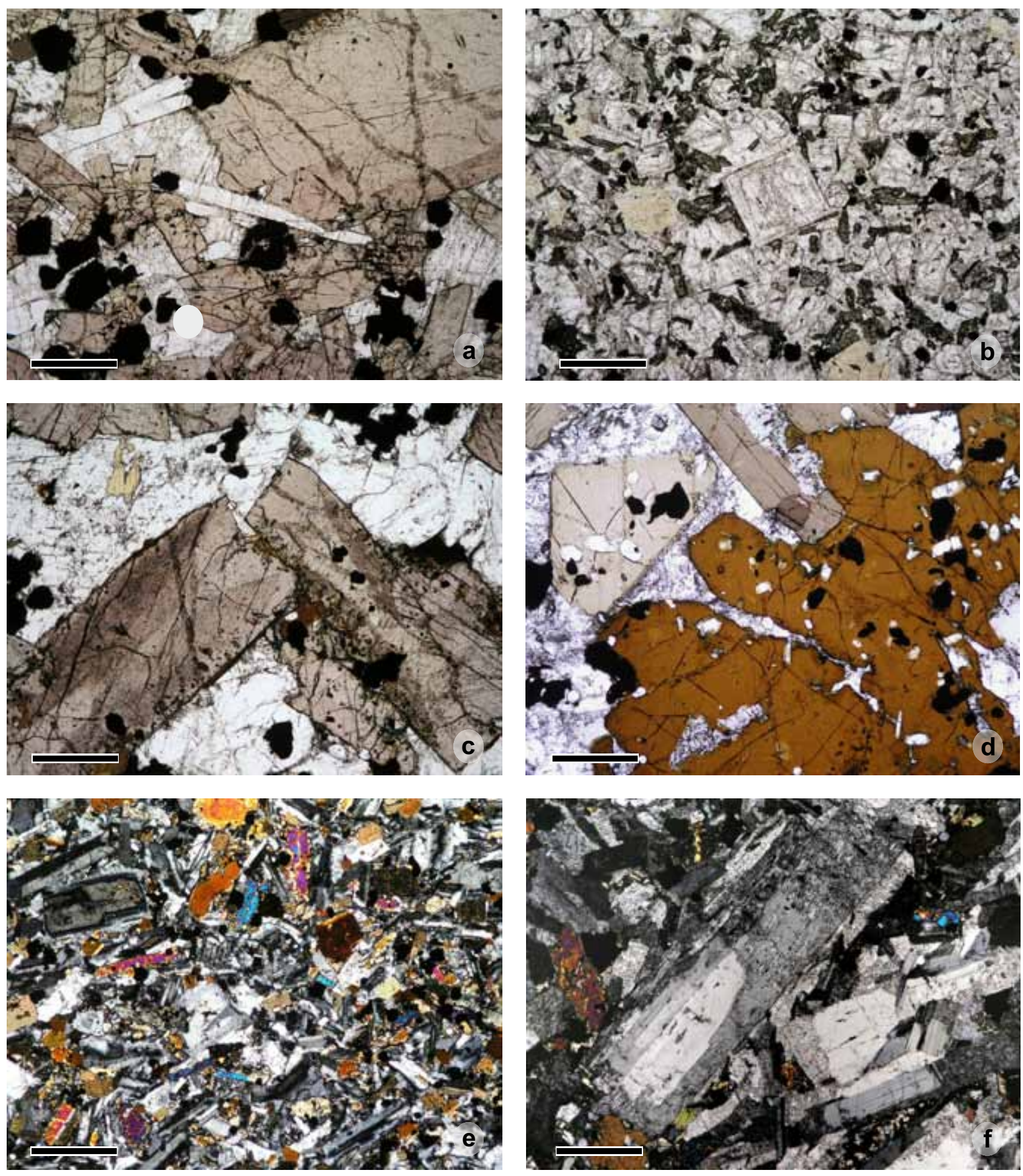

Fig. 4 Photomicrographs of mafic to felsic phaneritic rocks of the Doupov Intrusive Complex. a - Melteigite (melanephelinolite DH1550); b - Urtite (leuconephelinolite DR051B) rich in euhedral nepheline; c - Essexite (KY20A), a domain dominated by zoned clinopyroxene and anhedral nepheline; d - Essexite (KY20A), prevailing part rich in kaersutitic amphibole and interstitial plagioclase; $\mathbf{e}$ - Texture of monzodiorite with tabular plagioclase (crossed nicols); f - Porphyritic variety of sodalite monzosyenite with plagioclase overgrown by K-feldspar (crossed nicols). Bar is $0.5 \mathrm{~mm}$, plane-polarized light if not indicated otherwise. 


\subsection{Sodalite monzodiorite and similar varieties}

Sodalite-bearing monzodiorite occurs as small $(<1 \mathrm{~m})$ medium- to fine-grained dykes intruding clinopyroxenite breccias and other rocks in drill-core DB-2. The rock is dominated by plagioclase and the amount of interstitial $\mathrm{K}$-feldspar is highly variable. Mafic minerals consist of clinopyroxene and biotite, whereas hornblende occurs only rarely as inclusions in some plagioclase grains. Sodalite-bearing monzodiorite (Fig. 4e) may gradually pass into sodalite-bearing or sodalite monzonite.

\subsection{Sodalite-bearing monzosyenite to nepheline-sodalite (monzo)syenite}

Sodalite-bearing to sodalite monzosyenite constitutes one relatively thick $(\sim 4 \mathrm{~m})$ dyke exposed within a small old quarry NW of the summit Flurbühl (DI-4). Findings of rare homogeneous syenitic blocks (e.g., DR054) argue for existence of another relatively wide dyke(s) in the area. There are almost ubiquitous, innumerable, very thin dykes and veinlets crosscutting other rock types (Fig. 3c).

Relatively homogeneous syenitoids are felsic rocks dominated by sanidine, with less abundant plagioclase (andesine to oligoclase-andesine, commonly overgrown by sanidine), variable amounts of the sodalite group mineral(s) (nosean to sodalite, commonly euhedral but frequently altered) and rarely also nepheline (DH1322). Mafic minerals are minor and represented by dark mica (phlogopite to magnesian biotite; e.g., DH1322), brown hornblende (DR054) or by a combination of clinopyroxene, hornblende and mica (TV54). Accessory minerals consist of euhedral titanite, magnetite, ilmenite and tiny acicular apatite. The grain-size is variable but lengths of K-feldspar laths $\sim 1-3 \mathrm{~mm}$ are common. In a weakly porphyritic variety of sodalite syenite, plagioclase forms cores of K-feldspar phenocrysts (Fig. 4f) set in a finer grained, nearly trachytic matrix.

Thin dykes and veinlets (1-X0 mm in width) are commonly irregular, inhomogeneous and frequently rich in sodalite, especially in the marginal parts.

\subsection{Clinopyroxenites and clinopyroxenite breccias}

These rocks are very poorly exposed. On the present surface, they occur mostly as small xenoliths in other intrusive rocks or as small loose blocks without known original position. However, clinopyroxenites are the most widespread rock type in drill core DB-2 and seem to represent the oldest recognizable rock group intruded by sodalite-bearing monzodioritic to syenitic rock types and aphanitic dyke rocks.

Clinopyroxenites consist essentially of subhedral to anhedral clinopyroxene, which corresponds to almost unzoned or only weakly and irregularly zoned diopside. Clinopyroxene is commonly accompanied by variable amounts of phlogopite and magnetite, and much less frequently also apatite. Kaersutitic amphibole is present in some clinopyroxenite xenoliths (Fig. 5a) associated to essexite and sodalite syenite and representing ultramafic cumulate.

Clinopyroxenites in the DB-2 borehole are variable in grain size and texture even on a thin section scale. Phlogopite and magnetite are commonly present in various amounts (Fig. 5b). Some samples also contain apatite, pyrite and other minerals.

Brecciation of clinopyroxenites is accompanied by shattering of individual pyroxene grains. These crystals display an irregular network of microcracks marked by very fine phlogopite. Phlogopite may also form clusters of relatively coarse, often deformed flakes, in places with abundant and very sharp kink bands oriented in various directions (Fig. 5c).

Small felsic pockets (several $\mathrm{mm}$ in diameter) and veinlets are dominated at the margins by a sodalite mineral or its alteration products involving carbonate. The inner parts may approach the composition of sodalite syenite. These pockets and veins are frequently rimmed by kaersutitic amphibole and/or phlogopite, which partially replace the surrounding clinopyroxene grains.

\subsection{Phlogopite-clinopyroxene metasomatic rock ("pseudolamprophyre") and other products of thermal and metasomatic aureole}

Phlogopite-rich rock of lamprophyric appearance (macroscopically resembling coarse minette) occurs as large blocks at the eastern border of the DIC in close spatial association with ijolitic rocks and a thin dyke of nepheline-sodalite syenite. However, the microtexture strongly contrasts with lamprophyres and corresponds to a product of a metasomatic process superimposed on a pre-existing igneous, probably volcanic rock. Phlogopite flakes 1 to $10 \mathrm{~mm}$ and also clinopyroxene megacrysts $(1-4 \mathrm{~mm})$ are surrounded by a fine-grained, extremely inhomogeneous matrix. Phenocrystic clinopyroxenes are strewed with a network of microcracks invaded by fine-grained phlogopite (Fig. 5d) in the same manner as in clinopyroxenite breccias. "Phenocrystic" phlogopite may be deformed and, in places, partly replaced by fine-grained phlogopite aggregates. Other relatively large phlogopite 

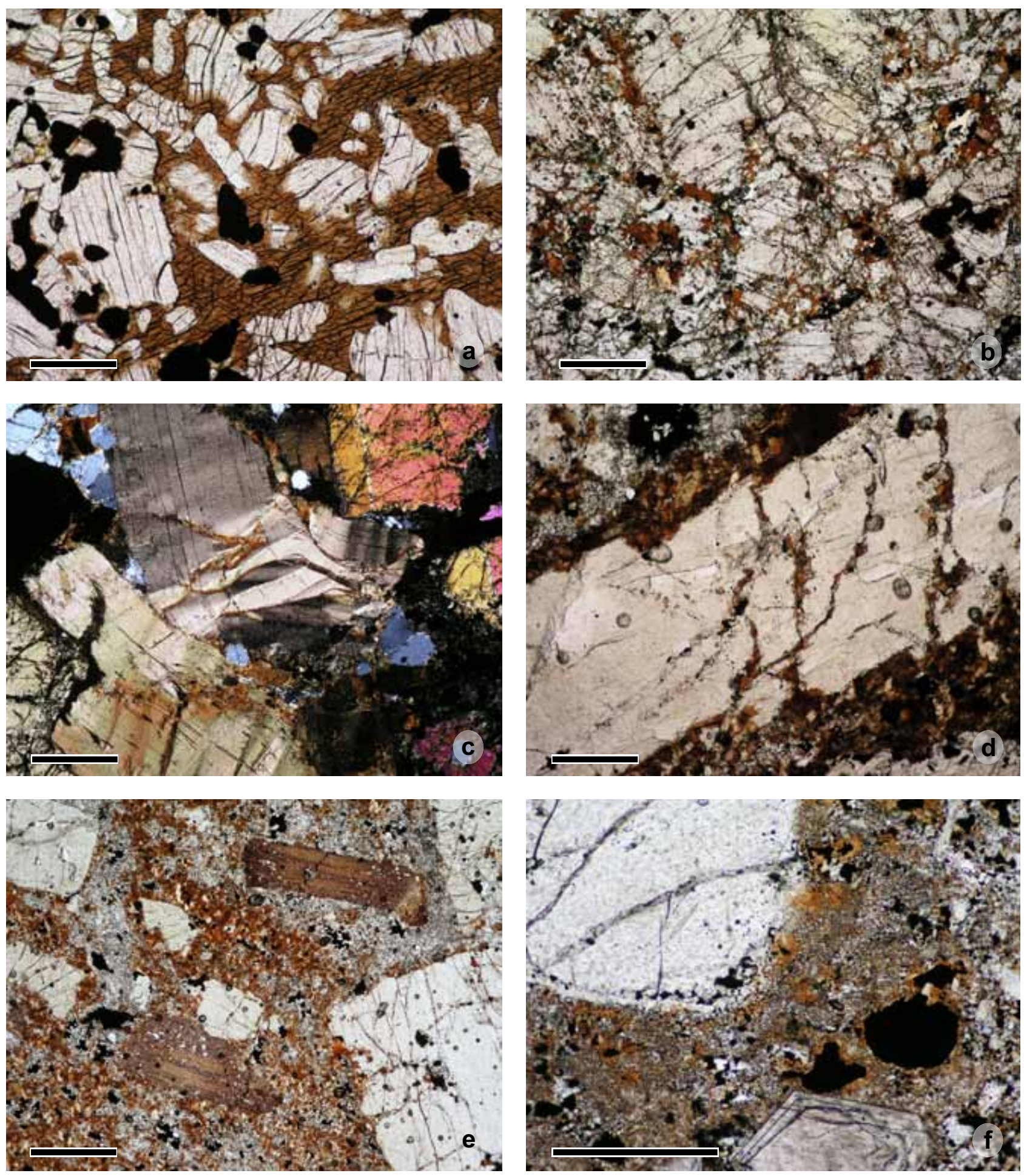

Fig. 5 Photomicrographs (plane-polarized light) of clinopyroxenites and metasomatized rocks of the Doupov Intrusive Complex. a - Clinopyroxenite with large interstitial and poikilitic kaersutite; $\mathbf{b}$ - Phlogopite-bearing clinopyroxenite with fine-grained phlogopite along grain boundaries and cracks within clinopyroxene grains; $\mathbf{c}$ - Large deformed phlogopite in coarse-grained clinopyroxenite, DB-2; d - Brittle deformation and partial phlogopitization along cracks of large clinopyroxene grain in metasomatic "pseudolamprophyre"; $\mathbf{e}$ - Phlogopitized matrix and large phlogopite flakes in metasomatized "pseudolamprophyre"; f - Phlogopitization of matrix in thermally affected microbreccia (matrix of vent breccia) from the top of Flurbühl. Bar is $0.5 \mathrm{~mm}$. 
crystals are undeformed but markedly poikilitic with minute clinopyroxene and magnetite inclusions. The matrix is fine-grained and inhomogeneous with some small domains highly dominated by phlogopite (Fig. 5e) and other completely devoid of this mineral, composed of pale greenish-yellow clinopyroxene $(0.015-0.05 \mathrm{~mm})$ with subordinate interstitial sodalite or its alteration products (zeolites with dispersed carbonate). Magnetite is minor, while iron sulphides and apatite represent accessory constituents.

The other samples are much poorer in fine phlogopite with mica forming individual poikilitic grains. Their fine-grained matrix is mostly "dry" with clinopyroxene dominating over fine magnetite and interstitial sodalite or K-feldspar plus sodalite. There are also irregular veins with a predominance of poikilitic K-feldspar enclosing many small euhedral inclusions of sodalite. Exactly the same fine-grained rock with scattered poikilitic flakes of phlogopite was found as small xenoliths in the sodalite monzodiorite dyke from the DB-2 borehole.

Breccias from the top of Flurbühl, i. e. located higher than essexite outcrops, contain fragments $\mathrm{X} \mathrm{mm}$ to $10 \mathrm{~cm}$ in size corresponding to highly variable fine-grained clinopyroxene-phyric mafic rocks that may represent chilled intrusive varieties of tephritic to basanitic composition and also monchiquitic lamprophyres. These fragments and also olivine and clouded clinopyroxene xenocrysts are cemented in a dense, aphanitic but highly inhomogeneous matrix resembling a microbreccia that was affected by thermal recrystallization. This matrix is characterized by the presence of finely scattered and locally concentrated biotite (Fig. 5f).

This unusual breccia type probably represents the fill of a pre-existing explosive conduit which was thermally reworked and metasomatized in the roof of the phaneritic alkaline intrusions.

\subsection{Lamprophyric dykes}

Thin dykes $(1 \mathrm{~cm}$ to $>0.5 \mathrm{~m})$ of lamprophyric rocks were found in abandoned drill-cores from the DP-3 borehole. The DB-2 drill-core contains lamprophyric rocks within the clinopyroxenite-dominated breccia as small, very irregular bodies that may be dykes or fragments.

Lamprophyres from DP-3 are aphanitic to fine-grained with very sharp, strongly chilled contacts. They contain phenocrysts of phlogopite, clinopyroxene and rare olivine 0.5 to $3 \mathrm{~mm}$ across. The groundmass contains various proportions of small acicular or blade-shaped crystals of phlogopite, amphibole and/or clinopyroxene set in a felsic matrix dominated by analcime, with dispersed fine-grained calcite and magnetite, and frequently also $\mathrm{K}$-feldspar. There are common occurrences of carbonatebearing zeolitic pseudomorphs, possibly replacing soda- lite. Some samples contain small round ocelli rimmed with tangentially arranged biotite and filled by analcime, carbonate, and frequently brown amphibole needles in a very fine felsic matrix.

\subsection{Felsic aphanitic dykes: trachytes to phonolites}

Trachytes, sodalite-bearing trachytes and phonolites were found as thin, very irregular dykes in drill-core DB-2. They are porphyritic with very fine-grained to aphanitic groundmass and consequently resemble effusive rocks. Judging from their textural features, these dykes intruded the already cold host rocks.

Trachytic varieties contain mafic phenocrysts of clinopyroxene plus hornblende or clinopyroxene (diopside) plus biotite. Other phenocrysts are sanidine and plagioclase (andesine to oligoclase) with sanidine overgrowths, in most cases also sodalite mineral(s), less frequently apatite and titanite. Some samples contain higher proportion of the sodalite mineral and pass into sodalite phonolite.

Sample DH745 from the NW vicinity of the Doupov Intrusive Complex represents an unusual variety of dyke phonolite with abundant euhedral phenocrysts of haüyne set in an extremely fine to cryptocrystalline, probably devitrified matrix. Clinopyroxene, which forms minute microliths, is rich in the aegirine component.

\section{Whole-rock geochemistry}

Selected representative whole-rock major- and trace-element analyses are presented in Tabs 3 and 4. A larger set of analyses, including those from the literature, is used for construction of variation diagrams (Figs 6-7) and other geochemical plots including that with chondritenormalized rare-earth element patterns (Fig. 8).

The analysed ijolitic rocks with "dry" mineral assemblage are strictly ultrabasic, extremely undersaturated with $\mathrm{Ne}+\mathrm{Lc}+\mathrm{Cs}$ ("larnite") in their CIPW norms, and metaluminous. The primitive nature of these rocks is expressed in the $\mathrm{MgO}$ contents, which are significantly higher than in essexites. Both melteigite DH1330 and ijolite DH1329 have very high contents of $\mathrm{CaO}$ with $\mathrm{TiO}_{2}$ but their $\mathrm{Na}_{2} \mathrm{O}$ and $\mathrm{K}_{2} \mathrm{O}$ are lower than in essexites. Melteigite and ijolite plot into the picrobasalt (close to foidite) and foidite fields, respectively. When comparing "dry" melteigite and ijolite, the latter is lower in $\mathrm{SiO}_{2}$ and $\mathrm{MgO}$ as well as compatible trace elements, namely $\mathrm{Cr}$, but higher in $\mathrm{TiO}_{2}, \mathrm{Al}_{2} \mathrm{O}_{3}$, total $\mathrm{Fe}, \mathrm{Na}_{2} \mathrm{O}, \mathrm{K}_{2} \mathrm{O}, \mathrm{P}_{2} \mathrm{O}_{5}$ and the whole spectrum of incompatible trace elements.

Olivine-phlogopite ijolite DR052 has $\mathrm{MgO}$ similar to the "dry" ijolite $\mathrm{DH} 1329$ but is higher in $\mathrm{SiO}_{2}, \mathrm{Al}_{2} \mathrm{O}_{3}$, $\mathrm{Na}_{2} \mathrm{O}, \mathrm{K}_{2} \mathrm{O}$ and lower in $\mathrm{TiO}_{2}, \mathrm{FeO}_{\text {tot }}, \mathrm{CaO}$ and $\mathrm{P}_{2} \mathrm{O}_{5}$. Its 
Tab. 3 Selected major-element data for the studied alkaline intrusive rocks (wt. \%)

\begin{tabular}{|c|c|c|c|c|c|c|c|}
\hline & 1 & 2 & 3 & 4 & 5 & 6 & 7 \\
\hline Sample & DH1330 & DH1329 & DR052 & DR051B & DI-8B & DI-3 & TV52 \\
\hline Rock & Melteigite & Ijolite & Mica ijolite & Urtite & Essexite & Essexite & Essexite \\
\hline $\mathrm{SiO}_{2}$ & 40.74 & 38.05 & 41.78 & 47.63 & 40.63 & 42.28 & 43.88 \\
\hline $\mathrm{TiO}_{2}^{2}$ & 4.629 & 5.453 & 3.79 & 1.67 & 4.15 & 3.98 & 3.755 \\
\hline $\mathrm{Al}_{2} \mathrm{O}_{3}$ & 9.57 & 10.71 & 12.26 & 22.05 & 11.87 & 13.33 & 13.28 \\
\hline $\mathrm{Fe}_{2} \mathrm{O}_{3}$ & 5.97 & 6.69 & 5.49 & 2.75 & $14.91 *$ & $13.53 *$ & $12.57 *$ \\
\hline $\mathrm{FeO}$ & 6.62 & 6.85 & 6.22 & 1.76 & n.a. & n.a. & n.a. \\
\hline $\mathrm{MnO}$ & 0.176 & 0.200 & 0.184 & 0.128 & 0.223 & 0.224 & 0.185 \\
\hline $\mathrm{MgO}$ & 11.06 & 8.28 & 8.41 & 0.99 & 6.27 & 6.01 & 5.96 \\
\hline $\mathrm{CaO}$ & 16.74 & 16.43 & 12.86 & 4.31 & 12.73 & 12.1 & 11.99 \\
\hline $\mathrm{SrO}$ & n.a. & n.a. & 0.09 & 0.41 & n.a. & n.a. & n.a. \\
\hline $\mathrm{BaO}$ & n.a. & n.a. & 0.11 & 0.21 & n.a. & n.a. & n.a. \\
\hline $\mathrm{Li}_{2} \mathrm{O}$ & n.a. & n.a. & 0.00 & 0.00 & n.a. & n.a. & n.a. \\
\hline $\mathrm{Na}_{2} \mathrm{O}$ & 1.47 & 1.60 & 2.70 & 7.58 & 2.74 & 2.99 & 3.25 \\
\hline $\mathrm{K}_{2} \stackrel{2}{\mathrm{O}}$ & 1.24 & 1.57 & 2.80 & 6.13 & 2.40 & 2.60 & 2.90 \\
\hline $\mathrm{P}_{2} \mathrm{O}_{5}$ & 0.44 & 1.15 & 0.59 & 0.15 & 1.23 & 0.94 & 0.66 \\
\hline $\mathrm{F}$ & 0.131 & 0.176 & 0.169 & 0.124 & n.a. & n.a. & 0.142 \\
\hline $\mathrm{CO}_{2}$ & 0.10 & 0.50 & 0.03 & 0.08 & n.a. & n.a. & 0.15 \\
\hline $\mathrm{SO}_{3}$ & n.a. & n.a. & n.a. & n.a. & n.a. & n.a. & 0.11 \\
\hline $\mathrm{S}$ & 0.017 & 0.017 & 0.09 & 0.04 & n.a. & n.a. & 0.147 \\
\hline $\mathrm{H}_{2} \mathrm{O}(+)$ & n.a. & n.a. & 1.88 & 3.18 & n.a. & n.a. & n.a. \\
\hline $\mathrm{H}_{2}^{2} \mathrm{O}(-)$ & 0.12 & 0.22 & 0.20 & 0.35 & n.a. & n.a. & 0.13 \\
\hline LOI & 0.77 & 1.53 & n.a. & n.a. & 1.55 & 0.93 & 0.92 \\
\hline Total & 100.40 & 99.52 & 99.66 & 99.55 & 98.71 & 98.92 & 99.35 \\
\hline$m g$ & 61.8 & 53.0 & 59.2 & 29.4 & 45.4 & 46.8 & 48.4 \\
\hline $\mathrm{K}_{2} \mathrm{O} / \mathrm{Na}_{2} \mathrm{O}$ & 0.84 & 0.98 & 1.04 & 0.81 & 0.88 & 0.87 & 0.89 \\
\hline \multirow[t]{2}{*}{$\mathrm{NK} / \mathrm{A}$} & 0.39 & 0.40 & 0.61 & 0.87 & 0.60 & 0.58 & 0.64 \\
\hline & 8 & 9 & 10 & 11 & 12 & 13 & 14 \\
\hline Sample & DI-8C & TV54 & DR048E & DB2 $48.8 \mathrm{~m}$ & DH1321 & DR048C & DH745 \\
\hline Rock & Essexite & Sdl. mnz-syenite & Vent breccia & Breccia & Metasom. rock & Monchiquite & Phonolite \\
\hline $\mathrm{SiO}_{2}$ & 48.71 & 56.00 & 37.84 & 37.49 & 40.49 & 41.29 & 52.06 \\
\hline $\mathrm{TiO}_{2}$ & 2.72 & 1.256 & 3.988 & 4.42 & 4.25 & 3.12 & 0.30 \\
\hline $\mathrm{Al}_{2} \mathrm{O}_{3}$ & 15.23 & 18.51 & 9.53 & 11.05 & 9.98 & 11.93 & 20.18 \\
\hline $\mathrm{Fe}_{2} \mathrm{O}_{3}$ & $9.94 *$ & 2.67 & $12.19^{*}$ & 10.75 & 5.67 & 5.75 & 2.60 \\
\hline $\mathrm{FeO}$ & n.a. & 1.91 & n.a. & 8.34 & 6.64 & 5.80 & 1.01 \\
\hline $\mathrm{MnO}$ & 0.189 & 0.126 & 0.145 & 0.241 & 0.159 & 0.181 & 0.256 \\
\hline $\mathrm{MgO}$ & 4.38 & 1.21 & 8.51 & 7.96 & 11.60 & 6.99 & 0.23 \\
\hline $\mathrm{CaO}$ & 9.82 & 4.82 & 13.31 & 12.49 & 14.17 & 12.62 & 2.60 \\
\hline $\mathrm{SrO}$ & n.a. & n.a. & n.a. & 0.078 & 0.046 & 0.09 & 0.253 \\
\hline $\mathrm{BaO}$ & n.a. & n.a. & n.a. & 0.060 & 0.079 & 0.09 & 0.168 \\
\hline $\mathrm{Li}_{2} \mathrm{O}$ & n.a. & n.a. & n.a. & 0.002 & 0.001 & 0.00 & 0.006 \\
\hline $\mathrm{Na}_{2} \mathrm{O}$ & 3.67 & 4.78 & 1.58 & 1.93 & 0.77 & 2.94 & 10.03 \\
\hline $\mathrm{K}_{2} \mathrm{O}$ & 3.37 & 5.43 & 2.10 & 2.03 & 2.86 & 2.48 & 7.04 \\
\hline $\mathrm{P}_{2} \mathrm{O}_{5}$ & 0.57 & 0.20 & 0.32 & 0.30 & 0.279 & 0.66 & 0.038 \\
\hline $\mathrm{F}^{2}$ & n.a. & 0.136 & n.a. & 0.14 & 0.131 & 0.132 & 0.106 \\
\hline $\mathrm{CO}_{2}$ & n.a. & 0.66 & n.a. & 0.21 & 0.23 & 2.82 & 0.26 \\
\hline $\mathrm{SO}_{3}$ & n.a. & 0.06 & n.a. & 0.18 & n.a. & n.a. & 1.07 \\
\hline $\mathrm{S}^{3}$ & n.a. & 0.036 & 0.023 & 0.22 & 0.725 & 0.12 & 0.026 \\
\hline $\mathrm{H}_{2} \mathrm{O}(+)$ & n.a. & n.a. & n.a. & 1.59 & 1.45 & 2.17 & 1.92 \\
\hline $\mathrm{H}_{2} \mathrm{O}(-)$ & n.a. & 0.34 & n.a. & 0.24 & 0.24 & 0.43 & 0.32 \\
\hline LOI & 1.19 & 2.41 & 9.18 & n.a. & n.a. & n.a. & n.a. \\
\hline Total & 99.78 & 99.61 & 98.69 & 99.73 & 99.72 & 99.61 & 99.39 \\
\hline$\overline{m g}$ & 46.6 & 33.0 & 58.0 & 46.0 & 63.8 & 53.2 & 10.5 \\
\hline $\mathrm{K}_{2} \mathrm{O} / \mathrm{Na}_{2} \mathrm{O}$ & 0.92 & 1.14 & 1.33 & 1.05 & 3.71 & 0.84 & 0.70 \\
\hline $\mathrm{NK} / \mathrm{A}$ & 0.64 & 0.74 & 0.51 & 0.49 & 0.45 & 0.63 & 1.16 \\
\hline
\end{tabular}

LOI - loss on ignition given for ICP-OES analyses from Activation Laboratories, Ltd.; $m g=100 \mathrm{Mg} /(\mathrm{Mg}+\mathrm{Fe}$ tot $)$ from atomic proportions; $\mathrm{K}_{2} \mathrm{O} / \mathrm{Na}_{2} \mathrm{O}$ based on wt. $\% ; \mathrm{NK} / \mathrm{A}=\left(\mathrm{Na}_{2} \mathrm{O}+\mathrm{K}_{2} \mathrm{O}\right) / \mathrm{Al}_{2} \mathrm{O}_{3}$ from molar values; * - total Fe as Fe $\mathrm{O}_{3}$ (ICP-OES analyses); n.a. - not analysed 
Tab. 4 Selected trace-element data (ppm) for the studied alkaline intrusive rocks

\begin{tabular}{|c|c|c|c|c|c|c|c|}
\hline & 1 & 2 & 3 & 4 & 5 & 6 & 7 \\
\hline Sample & DH1330 & DH1329 & DR052 & DR051B & DI-8B & DI-3 & TV52 \\
\hline Rock & Melteigite & Ijolite & Mica ijolite & Urtite & Essexite & Essexite & Essexite \\
\hline$\overline{\mathrm{Ba}}$ & 389 & 450 & 802 & 2171 & 579 & 856 & 780 \\
\hline Co & 52 & 51 & 43 & 7 & 52 & 38 & 44 \\
\hline $\mathrm{Cr}$ & 278 & 79 & $\underline{254}$ & $\leq 5$ & $<20$ & 20 & 37 \\
\hline Cs & 0.2 & 1.2 & 0.6 & 0.7 & 3.1 & 1.3 & 0.9 \\
\hline $\mathrm{Ga}$ & 20 & 23 & 20 & 26 & 24 & 22 & 22 \\
\hline $\mathrm{Hf}$ & 8.2 & 10.2 & 7.2 & 9.1 & 9.3 & 8.3 & 7.8 \\
\hline $\mathrm{Nb}$ & 61 & 71.4 & 87.1 & 333 & 72.3 & 68.1 & 83.4 \\
\hline $\mathrm{Ni}$ & 100 & 60 & 73 & 4 & 50 & 40 & 30 \\
\hline $\mathrm{Pb}$ & 2 & 5 & 4 & 3 & 9 & 9 & 5 \\
\hline $\mathrm{Rb}$ & 27 & 38 & 65 & 84 & 64 & 67 & 69 \\
\hline $\mathrm{Sc}$ & 62 & 43 & $\underline{33.9}$ & $\underline{1.5}$ & 28 & 24 & $\underline{27.1}$ \\
\hline $\mathrm{Sr}$ & 563 & 735 & 780 & 3352 & 738 & 1126 & 844 \\
\hline $\mathrm{Ta}$ & 4.22 & 5.36 & 6.29 & 20.70 & 5.29 & 5.52 & 5.98 \\
\hline V & 483 & 644 & 404 & 124 & 474 & 438 & 449 \\
\hline Y & 20.5 & 29.1 & 20.3 & 25.2 & 27.1 & 27.9 & 23.5 \\
\hline $\mathrm{Zr}$ & 317 & 420 & 312 & 601 & 340 & 316 & 311 \\
\hline $\mathrm{U}$ & 1.08 & 1.31 & 1.97 & 6.94 & 2.13 & 2.21 & 2.33 \\
\hline Th & 3.90 & 4.89 & 6.37 & 20.60 & 7.53 & 7.03 & 8.50 \\
\hline $\mathrm{La}$ & 39.0 & 65.4 & 53.6 & 96.8 & 72.1 & 71.2 & 63.4 \\
\hline $\mathrm{Ce}$ & 89.1 & 148 & 112 & 175 & 151 & 145 & 130 \\
\hline $\operatorname{Pr}$ & 11.8 & 19.4 & 13.5 & 17.4 & 17.7 & 17.4 & 15.5 \\
\hline $\mathrm{Nd}$ & 42.0 & 69.5 & 51.8 & 52.5 & 70.5 & 69.0 & 57.9 \\
\hline $\mathrm{Sm}$ & 8.15 & 12.50 & 9.29 & 7.99 & 12.00 & 11.90 & 10.40 \\
\hline $\mathrm{Eu}$ & 2.49 & 3.65 & 2.62 & 2.42 & 3.78 & 3.68 & 2.84 \\
\hline $\mathrm{Gd}$ & 7.27 & 11.20 & 6.80 & 5.66 & 9.07 & 9.04 & 7.76 \\
\hline $\mathrm{Tb}$ & 0.93 & 1.38 & 0.94 & 0.91 & 1.28 & 1.29 & 1.07 \\
\hline Dy & 4.43 & 6.33 & 4.58 & 4.96 & 6.21 & 6.29 & 5.36 \\
\hline Ho & 0.69 & 0.99 & 0.80 & 0.94 & 1.04 & 1.05 & 0.96 \\
\hline $\mathrm{Er}$ & 1.72 & 2.50 & 2.03 & 2.74 & 2.61 & 2.72 & 2.42 \\
\hline $\mathrm{Tm}$ & 0.213 & 0.314 & 0.250 & 0.397 & 0.347 & 0.359 & 0.324 \\
\hline $\mathrm{Yb}$ & 1.21 & 1.77 & 1.50 & 2.51 & 2.01 & 2.14 & 1.93 \\
\hline $\mathrm{Lu}$ & 0.170 & 0.233 & 0.201 & 0.343 & 0.275 & 0.297 & 0.267 \\
\hline
\end{tabular}

Underlined data were determined by INAA, others excepting Sc by ICP-MS, Sc by ICP-OES

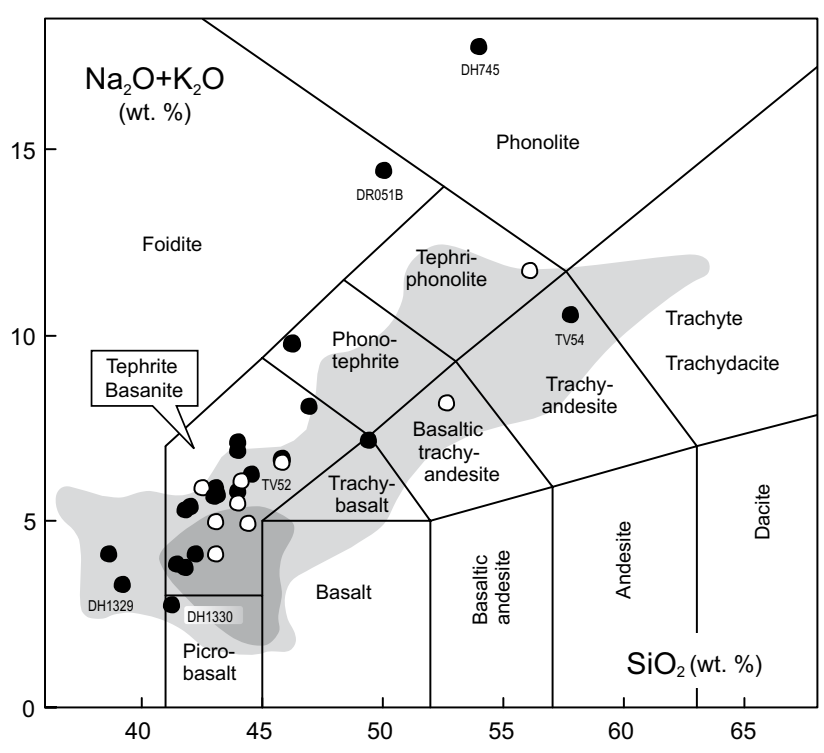

Fig. 6 Total-Alkali vs. Silica (TAS) diagram for phaneritic intrusions, breccias and aphanitic dyke rocks from the Doupov Intrusive Complex (black circles with numbers represent new samples, white circles are older analyses from literature). Compositional variability of lavas from the Doupovské hory Volcanic Complex is shown for comparison (shaded fields represent all literature analyses, dark one denotes the highest frequency of analyses). The IUGS classification grid for volcanic rocks is from Le Maitre et al. (2002). 
Tab. 4 continued

\begin{tabular}{|c|c|c|c|c|c|c|c|}
\hline & 8 & 9 & 10 & 11 & 12 & 13 & 14 \\
\hline Sample & DI-8C & TV54 & DR048E & DB2 $48.8 \mathrm{~m}$ & DH1321 & DR048ch & DH745 \\
\hline Rock & Essexite & Sdl. mnz-syenite & Vent breccia & Breccia & Metasom. rock & Monchiquite & Phonolite \\
\hline $\mathrm{Ba}$ & 927 & 987 & 660 & 529 & 564 & 689 & 2593 \\
\hline $\mathrm{Co}$ & 28 & 7 & 63 & 70 & 53 & 51 & 2 \\
\hline $\mathrm{Cr}$ & 60 & $<20$ & $\underline{157}$ & 45 & 113 & $\underline{169}$ & 7 \\
\hline $\mathrm{Cs}$ & 2.0 & 5.0 & 0.3 & 0.8 & 0.6 & 0.7 & 4.5 \\
\hline $\mathrm{Ga}$ & 26 & 24 & 21 & 23 & 18 & 23 & 41 \\
\hline $\mathrm{Hf}$ & 10.0 & 9.6 & 6.1 & 8.2 & 6.4 & 4.4 & 7.6 \\
\hline $\mathrm{Nb}$ & 102 & 93.8 & 50.4 & 76.2 & 58.2 & 66.7 & 173 \\
\hline $\mathrm{Ni}$ & 40 & 7 & 70 & 120 & 70 & 52 & 11 \\
\hline $\mathrm{Pb}$ & 14 & 20 & $<3$ & 10 & $<5$ & 8 & 25 \\
\hline $\mathrm{Rb}$ & 95 & 153 & 52 & 44 & 68 & 54 & 200 \\
\hline $\mathrm{Sc}$ & 19 & 4.2 & $\underline{61.2}$ & 49 & 67 & $\underline{36.9}$ & $<1$ \\
\hline $\mathrm{Ta}$ & 7.85 & 5.46 & 3.50 & 5.90 & 3.86 & 5.03 & 2.48 \\
\hline $\mathrm{V}$ & 309 & 136 & 447 & 603 & 413 & 393 & 87 \\
\hline $\mathrm{Y}$ & 33.7 & 19.5 & 14.7 & 23.3 & 17.2 & 20.6 & 5.9 \\
\hline $\mathrm{Zr}$ & 389 & 459 & 217 & 305 & 245 & 201 & 656 \\
\hline $\mathrm{U}$ & 3.56 & 4.54 & 1.10 & 1.44 & 0.73 & 1.74 & 13.50 \\
\hline $\mathrm{Th}$ & 12.80 & 17.10 & 4.01 & 4.75 & 3.79 & 5.92 & 43 \\
\hline $\mathrm{La}$ & 95.9 & 76.6 & 28.1 & 46.6 & 29.3 & 42.1 & 148 \\
\hline $\mathrm{Ce}$ & 196 & 136 & 66.3 & 101 & 72.4 & 96.8 & 206 \\
\hline $\operatorname{Pr}$ & 21.4 & 14.3 & 8.79 & 12.5 & 9.78 & 12.4 & 15.1 \\
\hline $\mathrm{Nd}$ & 80.2 & 46.6 & 39.5 & 50.2 & 35.5 & 52.9 & 35.5 \\
\hline $\mathrm{Sm}$ & 13.10 & 7.13 & 7.25 & 9.41 & 6.98 & 9.10 & 2.72 \\
\hline $\mathrm{Eu}$ & 3.83 & 1.85 & 2.05 & 2.62 & 2.07 & 2.61 & 0.74 \\
\hline Gd & 9.54 & 5.21 & 5.32 & 6.87 & 6.10 & 6.90 & 1.24 \\
\hline Dy & 7.12 & 3.88 & 3.41 & 4.90 & 3.74 & 4.59 & 0.80 \\
\hline Ho & 1.25 & 0.75 & 0.60 & 0.82 & 0.60 & 0.83 & 0.17 \\
\hline $\mathrm{Er}$ & 3.28 & 2.05 & 1.46 & 2.15 & 1.45 & 2.08 & 0.52 \\
\hline $\mathrm{Tm}$ & 0.451 & 0.303 & 0.151 & 0.283 & 0.186 & 0.237 & 0.082 \\
\hline $\mathrm{Yb}$ & 2.68 & 1.91 & 1.10 & 1.71 & 1.07 & 1.66 & 0.57 \\
\hline $\mathrm{Lu}$ & 0.375 & 0.276 & 0.148 & 0.257 & 0.143 & 0.226 & 0.099 \\
\hline
\end{tabular}

chemistry is more primitive (high $\mathrm{MgO}, \mathrm{Cr}$ ) but otherwise similar to the essexites.

Urtite (DR051B) is higher in silica (47.75 wt. \%) and much higher in alumina (22\%) and alkalis (sum $13.7 \%$ ) compared to ijolitic rocks. It is highly undersaturated and dominated in the CIPW norm by $\mathrm{Or}$ and $\mathrm{Ne}$. It is also metaluminous, although the molar $\left(\mathrm{Na}_{2} \mathrm{O}\right.$ $\left.+\mathrm{K}_{2} \mathrm{O}\right) / \mathrm{Al}_{2} \mathrm{O}_{3}$ ratio is moderately elevated (0.83). Of the incompatible trace elements, $\mathrm{Ba}, \mathrm{Sr}, \mathrm{Zr}, \mathrm{Nb}$ and $\mathrm{Ta}$ are strongly enriched, not only compared to mafic rocks, but also to the sodalite syenite. Compared with the rest of the dataset, this sample displays the lowest $\mathrm{Ti} / \mathrm{Nb}$ (30) and has a highly superchondritic $\mathrm{Zr} / \mathrm{Hf}$ ratio (66). No negative Eu-anomaly was observed (the slightly elevated Eu/ $\mathrm{Eu}^{*}$ value of 1.05 may be due to analytical uncertainty).

Essexites are alkaline, ultrabasic, rarely also basic, but invariably undersaturated ( $\mathrm{Ne}$-normative) rocks. The silica contents are in the range of $40.6-48.7 \mathrm{wt} . \%$ in the uncorrected analyses and 41.6-49.4 wt. \% (mostly $<45 \%)$ after recalculation to a volatile-free basis. The contents of $\mathrm{MgO}$ vary from $6.3 \%$ in the most primitive variety to $4.4 \%$ in the most evolved one. The $m g$ values calculated as $100 \mathrm{Mg} /\left(\mathrm{Mg}+\mathrm{Fe}_{\text {total }}\right)$ decrease with $\mathrm{MgO}$ from 48 to 40 . At the same time, the contents of $\mathrm{Al}_{2} \mathrm{O}_{3}$ and both $\mathrm{Na}_{2} \mathrm{O}$ and $\mathrm{K}_{2} \mathrm{O}$ increase, the latter from 2.4 to 3.4 wt. \%. The $\mathrm{K}_{2} \mathrm{O} / \mathrm{Na}_{2} \mathrm{O}$ ratios equal $0.75-0.92$. The contents of $\mathrm{TiO}_{2}$ and $\mathrm{P}_{2} \mathrm{O}_{5}$ decrease with decreasing $\mathrm{MgO}$ and they behave as compatible trace elements. All highly incompatible elements including $\mathrm{Rb}, \mathrm{Ba}, \mathrm{Th}, \mathrm{U}$, $\mathrm{Nb}, \mathrm{Ta}$, and LREE have high contents, typically $c .100 \times$ enriched in respect to the "primordial mantle" composition (Fig. 9).

Sodalite monzosyenite TV54, together with an older silicate analysis from the same locality (Shrbený 1982; values in parentheses), plots into the trachyandesite (or tephriphonolite) field of the Total Alkali-Silica diagram 

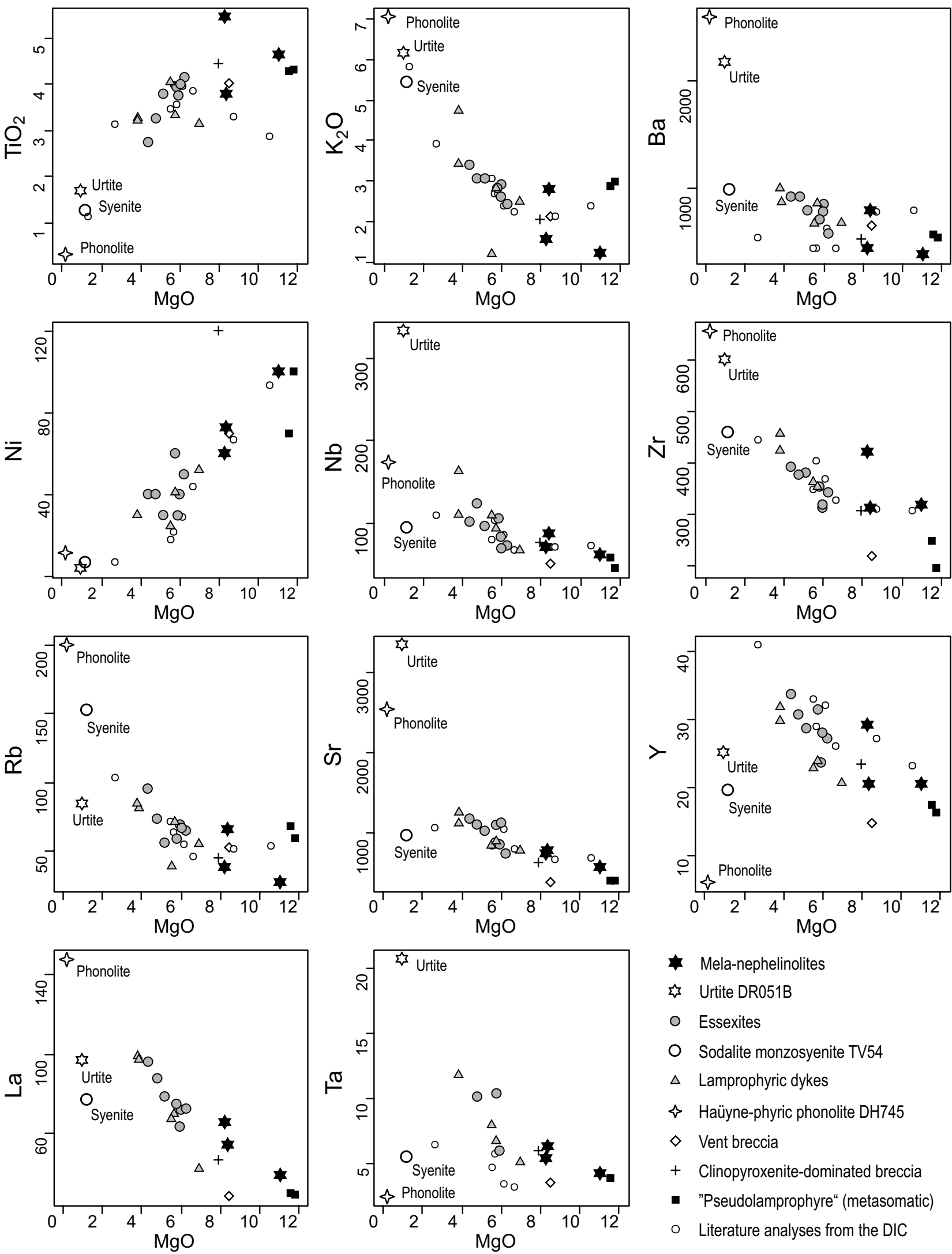
Mela-nephelinolites
s Urtite DR051B
○ Essexites
O Sodalite monzosyenite TV54
$\triangle$ Lamprophyric dykes
\& Haüyne-phyric phonolite DH745
$\diamond$ Vent breccia
+ Clinopyroxenite-dominated breccia
- "Pseudolamprophyre" (metasomatic)
- Literature analyses from the DIC

Fig. 7 Multiple variation diagrams of selected minor oxides (wt. \%) and trace elements (ppm) versus $\mathrm{MgO}$ (wt. \%) for all analyzed rocks from the Doupov Intrusive Complex and phonolite dyke DH745. 

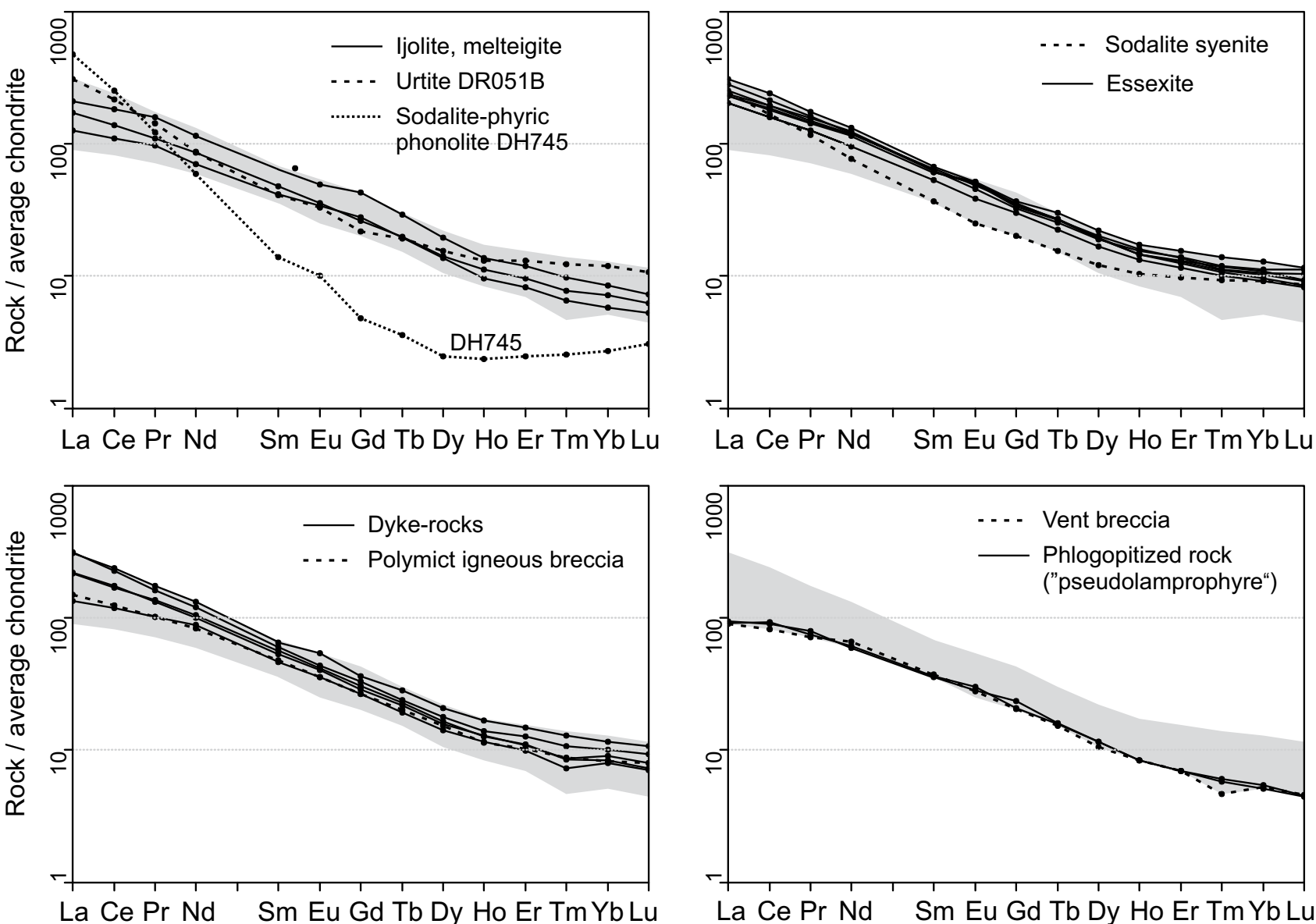

Fig. 8 Chondrite-normalized REE patterns of rocks from the Doupov Intrusive Complex. The grey field includes all samples apart for the sodalite-phyric phonolite dyke (DH745) from a locality NW of the DIC (Fig. 1). Normalization values are from Boynton (1984).

(Fig. 6). It is an alkaline intermediate rock containing $56.00(54.75)$ wt. $\% \mathrm{SiO}_{2}$ and $10.2(11.4)$ wt. \% of total alkalis with the $\mathrm{K}_{2} \mathrm{O} / \mathrm{Na}_{2} \mathrm{O}$ ratio of 1.14 (1.03). Sodalite monzosyenite is geochemically similar to trachytic rocks occurring as rare dykes in the surrounding lava sequences. It is metaluminous and An-normative with molar $\left(\mathrm{Na}_{2} \mathrm{O}+\mathrm{K}_{2} \mathrm{O}\right) / \mathrm{Al}_{2} \mathrm{O}_{3}<1(0.74)$. Normative $\mathrm{Ne}$ is low $(\sim 3.5$ wt. \%) and the CIPW norm is dominated by $A b$ and $O r$. Syenite is poor in compatible trace elements $\mathrm{Cr}$, Co and $\mathrm{Ni}$; $\mathrm{V}$ is rather high (136 ppm) although about three-times lower than in essexites. The contents of mantle-incompatible trace elements are roughly similar to those in essexite except for $\mathrm{Rb}, \mathrm{Cs}, \mathrm{Pb}$, Th, and $\mathrm{U}$, which have greatly elevated contents. Syenite displays only a weak negative Eu-anomaly (Eu/Eu* $\sim 0.9$, Fig. 8).

Phlogopite-clinopyroxene rock ("pseudolamprophyre") DH1321 is ultrabasic and highly magnesian (even more than melteigite). In a strong contrast to other mafic samples, it has ultrapotassic composition with $\mathrm{K}_{2} \mathrm{O} / \mathrm{Na}_{2} \mathrm{O}$ approaching 4. The contents of numerous trace elements are similar to other highly mafic rocks, except for $\mathrm{Sr}, \mathrm{Zr}, \mathrm{Hf}, \mathrm{Th}, \mathrm{U}$ and LREE, which are the lowest in the whole dataset.

\section{Isotopic composition ( $\mathrm{Sr}-\mathrm{Nd})$}

The results of isotopic analyses are listed in Tab. 5 . Isotopic data display subtle variations. The initial ${ }^{143} \mathrm{Nd} /{ }^{144} \mathrm{Nd}$ ratios, back-calculated for reference age of $30 \mathrm{Ma}$, display minimal differences $(0.51268-0.51279)$. The initial ${ }^{87} \mathrm{Sr} /{ }^{86} \mathrm{Sr}$ ratios fall within a broader range between 0.70358 and 0.70487 . The lowest value of ${ }^{87} \mathrm{Sr} /{ }^{86} \mathrm{Sr}$ (0.70358) was found for urtite (DR051B). The "wet" rock varieties tend to higher ${ }^{87} \mathrm{Sr} /{ }^{86} \mathrm{Sr}(>0.7042)$, whereby the sodalite monzosyenite has the highest ratio (0.70487).

Mafic phaneritic rocks isotopically correspond to the published $\mathrm{Sr}-\mathrm{Nd}$ data for lavas of the DHVC. Felsic varieties of both phaneritic and aphanitic intrusions display greater scatter (Fig. 10), perhaps due to lack of isotopic data from equivalent felsic lavas. 


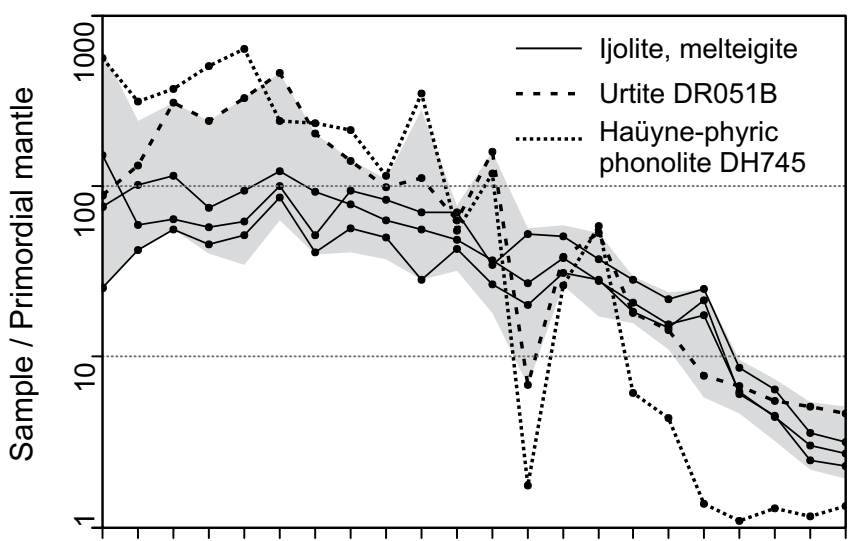

Cs Rb Ba Th U Nb K La Ce Pb Pr Sr P Nd Zr Sm Eu Ti Dy Y Yb Lu

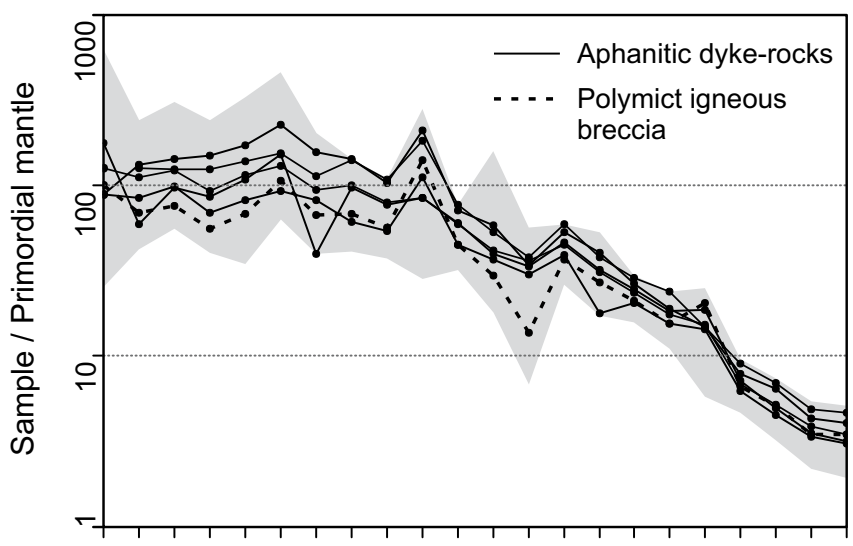

Cs Rb Ba Th U Nb K La Ce Pb Pr Sr P Nd Zr Sm Eu Ti Dy Y Yb Lu

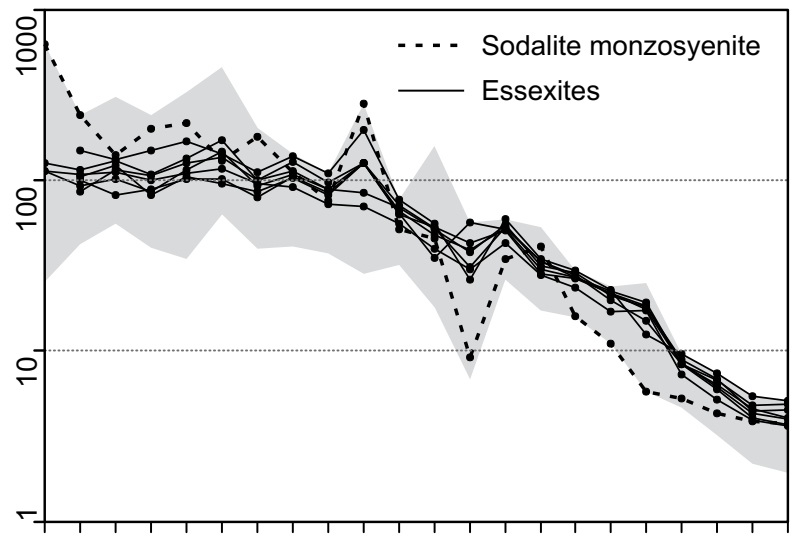

Cs Rb Ba Th U Nb K La Ce Pb Pr Sr P Nd Zr Sm Eu Ti Dy Y Yb Lu

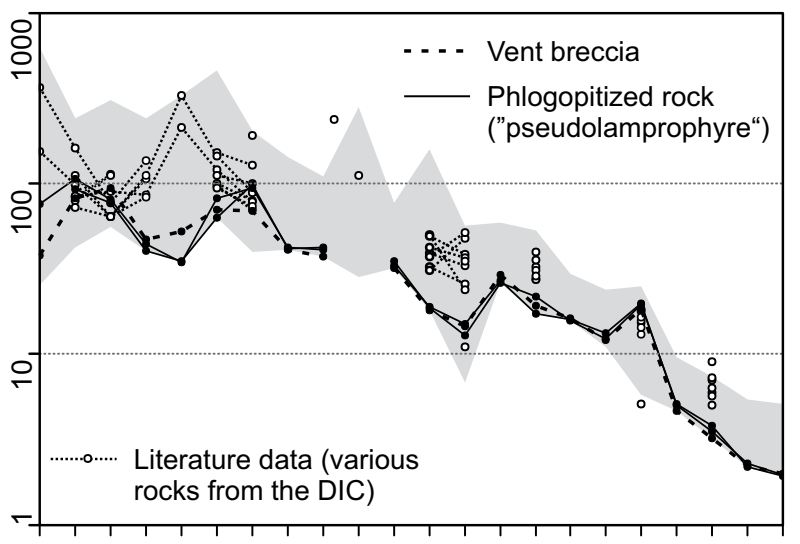

Cs Rb Ba Th U Nb K La Ce Pb Pr Sr P Nd Zr Sm EuTi Dy Y Yb Lu

Fig. 9 Trace-element concentrations normalized to the composition of the primordial mantle (Sun and McDonough 1989). Grey field contains all samples but the evolved phonolite dyke DH745.

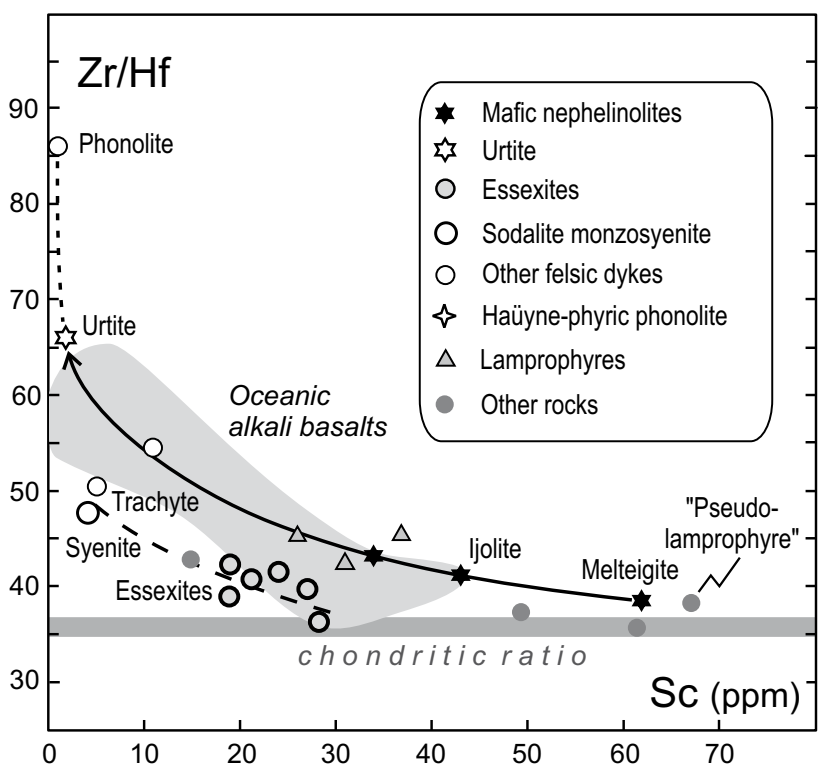

Fig. 10 Plot of $\mathrm{Zr} / \mathrm{Hf}$ ratios against Sc contents in rocks from the Doupov Intrusive Complex. Shown is also field for oceanic alkali basalts sensu lato and their derivatives (grey) after David et al. (2000).

\section{K-Ar geochronology}

Three bulk samples of intrusive rocks (melteigite, essexite and sodalite syenite), one metasomatically reworked igneous rock ("pseudolamprophyre") and also phlogopite megacrysts separated from vent breccia on the eastern margin of the DIC were dated using the $\mathrm{K}-\mathrm{Ar}$ method (Tab. 6).

All these five age determinations resulted in a very narrow time span from about $30.1 \pm 1.1$ to $28.0 \pm 0.9 \mathrm{Ma}$ and rank among the oldest published ages for the whole DHVC (cf. Ulrych et al. 2003; Rapprich and Holub 2008).

The new $\mathrm{K}-\mathrm{Ar}$ ages are nearly identical within analytical errors and cannot reflect temporal relations between individual intrusive pulses. The sodalite monzosyenite $(30.00 \pm 0.94 \mathrm{Ma})$ is, in fact, geologically younger than essexite $(27.96 \pm 0.89 \mathrm{Ma})$, even though their $\mathrm{K}-\mathrm{Ar}$ ages are statistically undistinguishable. 
Tab. $5 \mathrm{Sr}-\mathrm{Nd}$ isotopic data for the studied alkaline intrusive rocks

\begin{tabular}{|c|c|c|c|c|c|c|}
\hline Sample & DH1330 & DR051B & TV52 & TV54 & DH1321 & DH745 \\
\hline Rock type & Melteigite & Urtite & Essexite & $\begin{array}{c}\text { Sodalite } \\
\text { monzosyenite }\end{array}$ & $\begin{array}{c}\text { Metasom. r. } \\
\text { "Pseudolamprophyre" }\end{array}$ & $\begin{array}{c}\text { Haüyne-phyric } \\
\text { phonolite }\end{array}$ \\
\hline${ }^{87} \mathrm{Sr} /{ }^{86} \mathrm{Sr}$ (measured) & 0.703823 & 0.703608 & 0.704384 & 0.705060 & 0.704241 & 0.703884 \\
\hline 1 sigma & 0.000066 & 0.000078 & 0.000068 & 0.000063 & 0.000082 & 0.000037 \\
\hline $2 \mathrm{~S}(\mathrm{M})$ & 0.000010 & 0.000015 & 0.000013 & 0.000009 & 0.000016 & 0.000010 \\
\hline 1 sigma & 0.000045 & 0.000061 & 0.000040 & 0.000065 & 0.000052 & 0.000039 \\
\hline $2 \mathrm{~S}(\mathrm{M})$ & 0.000011 & 0.000011 & 0.000009 & 0.000019 & 0.000013 & 0.000008 \\
\hline$\left({ }^{87} \mathrm{Sr} /{ }^{86} \mathrm{Sr}\right)_{30}$ & 0.703766 & 0.703577 & 0.704283 & 0.704866 & 0.704029 & 0.703787 \\
\hline$\left({ }^{143} \mathrm{Nd} /{ }^{144} \mathrm{Nd}\right)_{30}$ & 0.512507 & 0.512565 & 0.512464 & 0.512469 & 0.512521 & 0.512609 \\
\hline
\end{tabular}

$\left({ }^{87} \mathrm{Sr} /{ }^{86} \mathrm{Sr}\right)_{30}$ and $\left({ }^{143} \mathrm{Nd} /{ }^{144} \mathrm{Nd}\right)_{30}$ are initial ratios corrected to the mean age of $30 \mathrm{Ma}$

$2 \mathrm{~S}(\mathrm{M})$ - two standard errors of the mean

Tab. 6 Results of $\mathrm{K}-\mathrm{Ar}$ dating

\begin{tabular}{|c|c|c|c|c|c|}
\hline Sample & DH1330 & DI-3 & TV54 & DH1321 & DH1364 \\
\hline Rock type & Melteigite & Essexite & $\begin{array}{c}\text { Sodalite } \\
\text { monzosyenite }\end{array}$ & "Pseudolamprophyre" & Vent breccia \\
\hline Material & bulk-rock & bulk-rock & bulk-rock & mica & mica \\
\hline $\mathrm{K}(\%)$ & 0.96 & 1.94 & 4.47 & 4.54 & 6.56 \\
\hline${ }^{40} \mathrm{Ar}_{\mathrm{rad}}(\mathrm{ccSTP} / \mathrm{g})$ & $1.092 \times 10^{-6}$ & $2.125 \times 10^{-6}$ & $5.254 \times 10^{-6}$ & $5.349 \times 10^{-6}$ & $7.472 \times 10^{-6}$ \\
\hline${ }^{40} \mathrm{Ar}_{\mathrm{rad}}(\%)$ & 51.5 & 70.8 & 76.0 & 49.8 & 73.3 \\
\hline $\mathrm{K}$-Ar age $(\mathrm{Ma})$ & $29.03 \pm 1.03$ & $27.96 \pm 0.89$ & $30.00 \pm 0.94$ & $30.06 \pm 1.09$ & $29.07 \pm 0.91$ \\
\hline
\end{tabular}

Ages are given at $1 \sigma$ confidence level

\section{Discussion}

\subsection{Comparison of the Doupov Intrusive Complex with other alkaline intrusive complexes associated with Cenozoic volcanic activity in the Bohemian Massif}

\subsection{1. České středohoří}

Shallow subvolcanic intrusive bodies of essexite, rongstockite (Ne-normative clinopyroxene-biotite monzodiorite) and sodalite syenite compositions from several localities within the so-called Roztoky Intrusive Centre or "main volcanic centre of České středohoří" are well known (e.g., Hibsch 1899, 1902; Ulrych et al. 1983; Ulrych 1998; Ulrych and Balogh 2000). Except for numerous dyke rocks displaying broader scatter of $\mathrm{K}-\mathrm{Ar}$ ages, the major intrusive bodies forming the so-called "Hypabyssal Weakly Alkaline Series" range from 33.1 to 28.2 Ma (Ulrych and Balogh 2000). Even though there is some non-systematic scatter, most of the data fall close to $30 \mathrm{Ma}$.

Despite the apparent parallelism in petrographic features of the essexitic and sodalite syenitic rocks in the two areas, some compositional differences do exist. The average composition of the Roztoky essexite is, e.g., higher in $\mathrm{SiO}_{2}$ but lower in $\mathrm{CaO}$ and $\mathrm{P}_{2} \mathrm{O}_{5}$, whereas sodalite syenite is lower in $\mathrm{SiO}_{2}$ but higher in $\mathrm{CaO}$ and $\mathrm{P}_{2} \mathrm{O}_{5}$ (see Ulrych 1998; Ulrych and Balogh 2000) compared to our analyses from Doupov. There is also a tendency towards lower $\mathrm{K}_{2} \mathrm{O} / \mathrm{Na}_{2} \mathrm{O}$ in the intrusive rocks from the Roztoky Intrusive Centre.

Xenoliths of plutonic alkaline rocks (hornblendite to amphibole clinopyroxenite, nepheline syenite) and also products of various stages of fenitization were found in the vent breccia of Koštál near Košt'álov at the S margin of the České středohoří (Kopecký 1966; Kopecký et al. 1970). Nephelinolites and larger bodies of clinopyroxenite in situ (except for small clinopyroxene-rich xenoliths) were not reported from the České středohoří area.

\subsubsection{Loučná}

Xenoliths up to $10 \mathrm{~cm}$ in size of phlogopite-bearing alkali clinopyroxenite and ijolite to urtite were described from the Loučná-Oberwiesenthal Volcanic Centre in the Krušné hory (Erzgebirge) Mts. (Ulrych et al. 2005). The locality is situated only $20 \mathrm{~km} \mathrm{NW}$ of the Doupov Intrusive Complex. The results of $\mathrm{K}-\mathrm{Ar}$ dating of various rocks from the complex vary significantly, ranging from 
51 to $31.2 \mathrm{Ma}$ (Pfeiffer et al. 1990) or 76.6 to $28.1 \mathrm{Ma}$ (Ulrych et al. 2005), most likely due to problems with trapped excess argon. Perhaps the most reliable age determination for a pyroxenite xenolith and thus also the host nephelinite is $29.7 \pm 1.2 \mathrm{Ma}$ (phlogopite from a clinopyroxenite xenolith; Ulrych et al. 2005). Therefore, at least some of the coarse-grained xenoliths were roughly contemporaneous with members of the Doupov Intrusive Complex. However, in contrast to the geological position of phaneritic rocks from Doupov, clinopyroxenite to ijolite and urtite xenoliths from the Loučná-Oberwiesenthal Volcanic Centre are currently interpreted as being derived from a (layered) mafic alkaline complex underplating the Variscan felsic basement at the crust-mantle boundary (Ulrych et al. 2005) or which was situated within the deep crust (Ulrych et al. 2006).

Published and newly presented geochronological data thus lead to interestingly similar ages for all the three centres - Roztoky, Loučná and Doupov - containing phaneritic alkaline rocks of plutonic appearance. Compositionally variable intrusive rocks from Doupov can be considered as counterparts of both the Hypabyssal Weakly Alkaline Series sensu Ulrych and Balogh (2000) from České středohoří and the highly undersaturated plutonic rocks forming xenoliths in the Loučná Volcanic Centre.

\subsection{Compositional relations between intrusi- ve rocks and lavas of the DHVC}

Essexitic and ijolitic rocks from the Doupov Intrusive Complex roughly correspond to basanites-tephrites and foidites, respectively (see, e.g., analyses of lavas in Shrbený 1982). Also the ranges of $\mathrm{Sr}$ and $\mathrm{Nd}$ isotopic compositions in intrusive rocks (except for $\mathrm{Sr}$ in syenite) are the same as those for "basaltic" lavas from the DHVC published by Vokurka (1997).

However, there is an apparent tendency towards a higher "Total Alkali" parameter in intrusive rocks from Doupov (Fig. 6). This is largely due to higher $\mathrm{K}_{2} \mathrm{O}$ contents in the mafic intrusive rocks compared to compositionally similar lavas of the DHVC. This contrast can be explained by distinct mineral assemblages and their ability to fix potassium. Lavas containing glass and/or leucite are susceptible to low-temperature alterations involving exchange of alkalis with water and replacement of leucite by analcime; as a consequence, many lavas of the DHVC display a partial loss of K (cf. Rapprich 2003). Contrary to lavas, phaneritic intrusive rocks have $\mathrm{K}_{2} \mathrm{O}$ fixed in amphiboles, biotite, $\mathrm{K}$-bearing nepheline and $\mathrm{K}$-feldspar. Their $\mathrm{K}_{2} \mathrm{O}$ contents may thus reflect the original contents in the parental magmas better than in the lavas. Some phaneritic rocks, however, may represent cumulates and their composition does not have to correspond to that of the original magma. Moreover, the composition of intrusive rocks, namely those with "wet" mineralogy, may be affected by metasomatic processes leading to significant redistribution of elements. In the Doupov Intrusive Complex proper, we have to consider operation of potassic metasomatism, which is manifested by partial phlogopitization of clinopyroxene and some other minerals.

\subsection{Constraints on the mantle sources for mafic magmas}

The alkaline, undersaturated compositions and the incompatible trace-element patterns with high contents of HFSE (see the multielement normalization "spider" plots, Fig. 9) are in accord with the anorogenic, extensional (rift-related) intraplate setting of the Doupov intrusive rocks as well as the whole DHVC and also a number of other volcanic complexes and occurrences over Western and Central Europe (see, e.g., Wilson and Downes 1991, 2006; Lustrino and Wilson 2007).

The nature of the mantle sources can be evaluated from composition of the most primitive mafic igneous rocks. For instance, Lustrino and Wilson (2007) selected only analyses with $\mathrm{MgO}>7 \mathrm{wt} . \%$. These rocks are rare in the DIC and some of them are far from representing the original magma composition, being rather heterogeneous breccias, cumulitic or metasomatized rocks.

The most primitive mafic rocks in the DIC are highly mafic nephelinolites - melteigite (DH 1330) and ijolites (DH1329 and DR052). The latter sample is, however, "wet" with abundant mica and also geochemically different from the "dry" nephelinolites.

Mafic melts with various degrees of undersaturation can be theoretically derived from a homogeneous peridotitic source by various degrees of partial melting; such simple relationships between mafic magmas occurring even within a limited area are, however, seldom the case (Bogaard and Wörner 2003) and an origin in geochemically heterogeneous mantle sources must be taken into account.

Although mafic nephelinolites and essexites share many geochemical features, there are some subtle differences, e.g., in their $\mathrm{Zr} / \mathrm{Hf}$ ratios (Fig. 11) and also in evolution of this parameter towards more fractionated rocks. There are two evolutionary trends, one involving the more undersaturated nephelinolites and their counterparts among dykes, the other consisting of essexites and relatively less undersaturated felsic rocks. Systematic differences also appear in some other elemental ratios, such as $\mathrm{Ce} / \mathrm{Pb}, \mathrm{Nb} / \mathrm{U}$ (both being higher in nephelinolites) and $\mathrm{Ba} / \mathrm{Nb}$ (higher in essexites), which apparently confirm some distinctness of the two rock varieties.

Dupuy et al. (1992) explained the increased $\mathrm{Zr} / \mathrm{Hf}$ ratios in some undersaturated mafic lavas from oceanic 


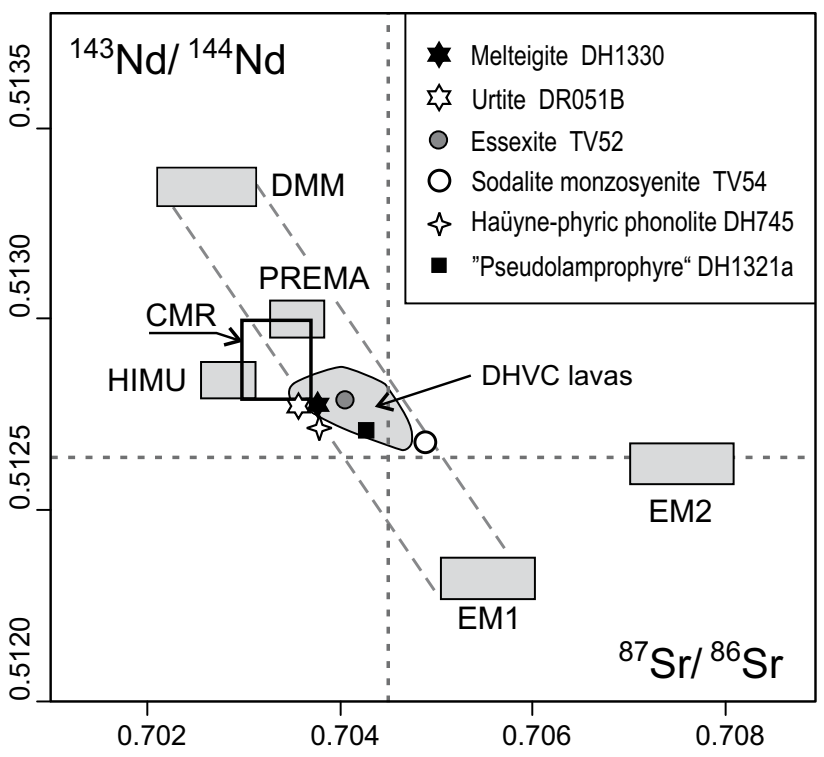

Fig. 11 Diagram of ${ }^{143} \mathrm{Nd} /{ }^{144} \mathrm{Nd}$ vs. ${ }^{87} \mathrm{Sr} /{ }^{86} \mathrm{Sr}$ in various rock types from the Doupov Intrusive Complex. Mantle components as defined by Zindler and Hart (1986): DMM - Depleted MORB Mantle; PREMA Prevalent Mantle; HIMU - high $\mu\left({ }^{238} \mathrm{U} /{ }^{204} \mathrm{~Pb}\right)$ component of ocean island basalts; EM I - component of Enriched Mantle with a low $\mathrm{Sm} / \mathrm{Nd}$ ratio leading to low ${ }^{143} \mathrm{Nd} /{ }^{144} \mathrm{Nd}$; EM II - component of Enriched Mantle with high $\mathrm{Rb} / \mathrm{Sr}$ and ${ }^{87} \mathrm{Sr} r{ }^{86} \mathrm{Sr}$. Other abbreviations: CMR - Common Mantle Source (Lustrino and Wilson 2007); DHVC - field of published isotopic data for lavas from the Doupovské hory Volcanic Complex.

islands in terms of carbonatitic metasomatism in their mantle source. According to Fujinawa and Green (1997), these increased $\mathrm{Zr} / \mathrm{Hf}$ ratios may reflect not only the mantle source metasomatically overprinted by interaction with carbonatite fluid, but also the presence of residual hornblende in the source domain. On the other hand, David et al. (2000) came to the conclusion that not the mantle heterogeneity, but a different extent of melting may be the major factor controlling the $\mathrm{Zr} / \mathrm{Hf}$ variations in primitive magmas.

Isotopic data ( $\mathrm{Sr}$ and $\mathrm{Nd}$ ) for rocks of the DIC do not deviate from those published for lavas of the DHVC, České středohoří and other alkaline volcanic rocks of the Bohemian Massif. They appear as relatively primitive in the whole isotopic data scatter for mafic lavas of the anorogenic Central and West European Cenozoic igneous province (Lustrino and Wilson 2007). Nephelinolites from Doupov including the evolved urtite (DR051B) are isotopically very close to the European Asthenospheric Reservoir (EAR, Cebriá and Wilson 1995; Wilson and Downes 2006) or the Common Mantle Reservoir (CMR, Lustrino and Wilson 2007), representing a dominant, sub-lithospheric magma source region beneath the Central and Western European volcanic complexes (Fig. 10).

Isotopic composition of urtite is very similar to highly mafic melteigite DH1330. The ${ }^{87} \mathrm{Sr}{ }^{86} \mathrm{Sr}$ ratio of the urtite is even the lowest among all the analysed samples.
Therefore, the modification of urtite composition by contamination with continental crust was likely negligible. The highly undersaturated urtite can be interpreted as a fractionation product of the parental ijolitic magma.

The remaining samples have $\mathrm{Sr}$ isotopic compositions significantly more radiogenic. Such shift to higher ${ }^{87} \mathrm{Sr} /{ }^{86} \mathrm{Sr}$ ratios may imply contamination with more evolved crustal material. Increased $\mathrm{Sr}$ isotopic ratios (0.70443-0.70465) were documented from trachybasaltic lavas of the Upper Formation in the České středohoři Mts. and interpreted in terms of fractionation combined with crustal contamination (Cajz et al. 1999; Ulrych et al. 2002). On the other hand, as demonstrated by Downes (2001), the compositional extent of enriched domains within the European lithospheric mantle spans up to ${ }^{87} \mathrm{Sr} r{ }^{86} \mathrm{Sr} \sim 0.706$. This implies that even melts with such high values can simply be derived by partial melting of the local mantle source, without any assimilation of the crust. Therefore, the sole essexite sample displays a more apparent lithospheric signature in terms of its $\mathrm{Sr}$ isotopic ratio but its crustal contamination cannot be proved.

\subsection{Petrogenetic relations between various phaneritic intrusive rocks in the Doupov Intrusive Complex}

\subsubsection{Mafic nephelinolite}

Nephelinolites are the most undersaturated rocks of the Doupov Intrusive Complex. The "dry" varieties form a distinct group that probably evolved separately and can be evaluated independently from the "wet" rocks. The most primitive sample with $m g \sim 62$, Cr $278 \mathrm{ppm}$, Ni $100 \mathrm{ppm}$ and Sc $62 \mathrm{ppm}$ is melteigite DH1330. The composition of ijolite DH1329 is characterized by lower $m g$ (53), $\mathrm{Cr}, \mathrm{Ni}$, and $\mathrm{Sc}$ (79, 60 and $43 \mathrm{ppm}$, respectively) and systematically higher contents of all the typically incompatible elements.

If there is a direct petrogenetic link between these two compositions, we can consider three possibilities: (1) melteigite was derived from the ijolite magma through accumulation of mafic phases, (2) both ijolite and melteigite originated by crystal accumulation from a common parental magma, and (3) ijolite represents a more evolved composition generated from the parental melteigite magma by crystal fractionation. This latter scenario is preferred and modelled in detail by Haloda et al. (this volume).

Going from melteigite DH1330 to ijolite DH1329, the drop in the $\mathrm{Cr}$ contents accompanied by a significant decrease in Ni and Sc are consistent with loss of ultramafic cumulates dominated by clinopyroxene but also containing some olivine at an early stage (see Haloda et al. this volume). The fractionation model can even per- 
fectly explain the lower silica content in ijolite compared with melteigite, as the crystal extract has $\mathrm{SiO}_{2}$ higher than the parental magma composition (see also the Total Alkali - Silica plot, Fig. 6). There are, however, some discrepancies in $\mathrm{P}_{2} \mathrm{O}_{5}$ (being too high in ijolite) and in the enrichment factors of various strongly incompatible elements (e.g., LREE are enriched in the ijolite sample systematically more than $\mathrm{K}, \mathrm{Rb}, \mathrm{Ba}$, Th and $\mathrm{U}$ ). Cobalt with nearly the same contents in both melteigite and ijolite is also rather problematic; when we consider the high olivine/melt partition coefficient for Co (e.g., Lemarchand et al. 1987), mildly incompatible behaviour of Co in the clinopyroxene/liquid equilibrium is required. The distribution of Cs is quite erratic and cannot be modelled by crystal fractionation.

\subsubsection{Urtite}

Urtite is a highly undersaturated felsic rock type and could seldom be petrogenetically linked with the much less undersaturated rocks of the Doupov Intrusive Complex. Therefore, we propose derivation of urtite from a more mafic and highly undersaturated magma of ijolitic or melteigitic composition. However, the geochemical features of urtite correspond to a highly evolved melt and the compositional gap between ijolite and urtite or melteigite is too large for quantitative modelling of fractional crystallization.

When we compare the compositions of urtite and melteigite, the enrichment factors of incompatible elements (concentration in urtite/concentration in melteigite) are very variable. The highest value (6.43) is displayed by uranium, which can be considered to be an "almost perfectly" incompatible element during fractionation. Uranium is closely followed by $\mathrm{Sr}$ (5.95), Ba (5.58), $\mathrm{Nb}$ (5.46) Th (5.28), and Ta (4.91). Urtite is also highly enriched in $\mathrm{Na}(5.16)$ and $\mathrm{K}(4.94)$ but less enriched in $\mathrm{Cs}$ (3.5) and $\mathrm{Rb}$ (3.1). Even lower enrichment factors are typical of $\mathrm{Zr}$ (1.90) and Hf (only 1.11). Both LREE and HREE are moderately enriched whereas the middle rare earth elements (MREE) are depleted in urtite compared to melteigite.

The highly superchondritic $\mathrm{Zr} / \mathrm{Hf}$ ratio combined with very low Sc content in urtite (Fig. 11) argue for strong fractionation of clinopyroxene in the same manner as in alkaline basaltic magmas from oceanic islands (see David et al. 2000). This is caused by the significantly higher partition coefficient for $\mathrm{Hf}$ than for $\mathrm{Zr}$ in clinopyroxene (e.g., Lemarchand et al. 1987; Hart and Dunn 1993). The effect could be further enhanced by co-precipitation of titanite and magnetite.

Urtite displays a weak tendency towards a convexdown curve of chondrite-normalized REE concentrations in Fig. 8. This feature is enhanced and much more

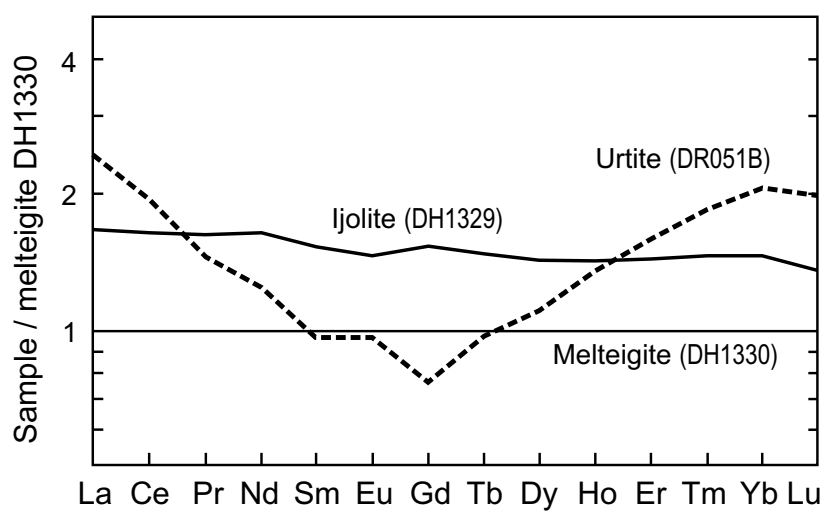

Fig. 12 Abundances of rare-earth elements in ijolite and urtite normalized by concentrations in melteigite DH1330. The convex-down curve of urtite is explained by fractionation of titanite.

obvious in Fig. 12, where normalization with the most primitive melteigite is employed. Here it is apparent that the origin of the convex-down curve for ijolite requires fractionation of some mineral with strong preference for the middle rare-earth elements (MREE). Green and Pearson (1986) and Lemarchand et al. (1987) have shown that the convex-down partitioning pattern with strong favouring of the middle rare earths (MREE) is typical of titanite. Moreover, titanite strongly favours Ta and its fractionation will increase $\mathrm{Nb} / \mathrm{Ta}$ ratio in the melt (Tiepolo et al. 2002). An increase in $\mathrm{Nb} / \mathrm{Ta}$ is also observable in urtite. As titanite in variable amounts and relatively large, well-shaped crystals is typically present in our rocks, we consider its significant role in the relatively late stages of the fractionation process to be proven.

The increase in the silica content towards urtite cannot be explained by fractionation of clinopyroxene alone and the effect of titanite is insufficient due to its limited quantity. Therefore, fractionation of the mineral phases with low or negligible $\mathrm{SiO}_{2}$ is required. The most important candidate is magnetite, which was definitely accompanied by a limited amount of apatite, as the only explanation for the obvious decrease in $\mathrm{P}_{2} \mathrm{O}_{5}$.

Evolution of melteigite magma represented by DH1330 to the composition of urtite DR051B through fractionation of the above-mentioned anhydrous minerals cannot explain the variations in $\mathrm{K}, \mathrm{Rb}$ and $\mathrm{Cs}$. Either phlogopite/biotite concentrating $\mathrm{Rb}$ and $\mathrm{Cs}$ played a subordinate role or these three elements were partially redistributed in a fluid phase.

The strongly undersaturated dyke of phonolite DH745 representing the only sample of peralkaline chemistry is also isotopically close to phaneritic nephelinolites. It can be considered to be an extremely evolved composition (the $m g$ value is only about 10 ) derived by prolonged fractional crystallization from a nephelinolitic parental magma to similar to that for the urtite. Its very high $\mathrm{Zr} /$ Hf, very strongly convex-down REE pattern and greatly 
increased $\mathrm{Nb} / \mathrm{Ta}$ ratio argue for advanced clinopyroxene and titanite fractionation during a late evolutionary stage of felsic alkaline magma. The subtle decrease in $\mathrm{Al}_{2} \mathrm{O}_{3}$ and the origin of the weakly peralkaline character may be due to late fractionation of haüyne.

\subsubsection{Essexite}

Essexites are typically "wet" and their most mafic samples have $\mathrm{MgO} \sim 6$ wt.\%. Their low $m g$ values $(<48.5)$ as well as low $\mathrm{Cr}$ and $\mathrm{Ni}$ are far from values typical of primary melts equilibrated with the mantle sources and indicate significantly more evolved composition compared to mafic nephelinolites. Essexites are less undersaturated than nephelinolites and it is highly probable that also their parental mafic magmas shared this feature. The relatively low $\mathrm{Ni}$ and $m g$ values in essexites as a group argue for prior separation of olivine-rich cumulates, which would be left within a deeper magma chamber or at the walls of deep channels for magma ascent. The chemical changes from the most to least mafic varieties of essexites may be attributed to the fractionation of clinopyroxene accompanied by some titanite, magnetite, and apatite. However, the existence of considerable scatter in elemental abundances and ratios is inconsistent with a simple evolutionary trend common for all the analysed varieties of essexitic rocks.

\subsubsection{Sodalite monzosyenite}

In contrast to urtite, which is similarly evolved in terms of low $m g$ values and contents of compatible elements, sodalite monzosyenite is much less undersaturated. Moreover, it is poorer in some incompatible elements, namely $\mathrm{Ba}, \mathrm{Sr}, \mathrm{Nb}$, and $\mathrm{Zr}$ but richer in some others, especially $\mathrm{Rb}$. Moreover, the rock displays a weak negative Eu-anomaly. Such geochemical features are interpreted in terms of a different parental magma (weakly undersaturated) and fractionation of feldspars as well as mafic minerals.

Although there is some geochemical affinity to the group of essexitic rocks, a true genetic relationship can hardly be established. Syenite is definitely intrusive into essexites at the present erosion level and the possible existence of a common parental magma at depth is obscured by younger processes. The isotopic composition of the sodalite monzosyenite TV54 is significantly shifted away from the CMR field towards the magmas of dominantly lithospheric sources or contaminated by crustal material (Fig. 10). As such a composition has no counterpart among more mafic rocks from the whole DHVC (including essexite TV52), this shift may be ascribed to limited contamination by the (upper) continental crust.
Small volumes of sodalite syenite forming thin dykes and veinlets in mafic and ultramafic rocks may have locally evolved from dykes of sodalite monzodiorite. Insufficient data are currently available for these rocks.

\subsubsection{Clinopyroxenite and clinopyroxenite breccia}

Due to their extreme composition and by analogy with many other alkaline complexes over the world, clinopyroxenites may be considered to be ultramafic cumulates derived from mafic alkaline magmas. Their textural features argue for accumulation of magnetite, apatite and phlogopite in addition to the highly dominant clinopyroxene.

Clinopyroxenites in the Doupov Intrusive Complex could be genetically linked to both the ijolitic and essexitic parental magmas. A genetic link with foidite and basanite-tephrite lavas is also possible. However, such a small and very shallow intrusive complex can hardly be interpreted as a magma chamber in which crystal fractionation processes could have operated effectively.

Another possibility is origin of clinopyroxenite cumulates within a long-lasting deeper magma chamber or a system of feeding channels, with subsequent explosive destruction of cumulates and quick transport of clinopyroxenite fragments and hot fluids as a fluidized system up to the present position. Some petrographic and geological features of clinopyroxenites are consistent with this idea, especially:

- extensive brecciation of clinopyroxenites,

- very frequent presence of abundant microcracks within individual clinopyroxene grains,

- strong deformation of large phlogopite flakes (cumulus mica) present in some samples,

- relative temporal relations - where geological relationships are observable, clinopyroxenites behave as the oldest member of the complex (namely in the DB-2 drill core) and are intruded by sodalite (monzo-) diorite to sodalite syenite,

- widespread evidence that these rocks were invaded by very hot fluids and melts shortly after but perhaps even during their emplacement.

\subsection{Presence of carbonatite intrusion beneath Flurbühl: fact or fiction?}

Kopecký (e.g., 1987, 1987-1988, 2010; Kopecký et al. 1970) took great pains to demonstrate the presence of carbonatites in České středohoří Mts. Kopecký (1988) expressed his belief that carbonatite intrusions are also present below the Loučná and Doupov volcanic centres. 
The DHVC was not found to contain any rock type that could be considered to be carbonatite. Therefore, we can discuss the problem only from these two viewpoints: (1) silicate rock association of the Doupov Intrusive Complex, and (2) record of metasomatic processes that could be eventually ascribed to carbonatite.

\subsubsection{Rock association}

The clinopyroxenite-foid syenite, melteigite-ijolite-urtite and also essexite-foid syenite are rock assemblages that are very frequently associated with intrusive carbonatites (Wooley 2003; Wooley and Kjarsgaard 2008). The clinopyroxenite breccias are "classic" counterparts of many carbonatite intrusions of variable ages and in various parts of the world including, e.g., the Palaeozoic Kola carbonatite province of Baltica. Felsic alkaline rocks in carbonatite-silicate rock associations are either peralkaline nephelinolites and foid syenites including strongly agpaitic nepheline syenites, or metaluminous including miaskitic nepheline syenites and monzosyenites. Therefore, the fact that alkaline rocks from the DIC are metaluminous (apart from the dyke of the extremely fractionated sodalite phonolite DH745 with agpaitic chemistry) is not contradictory to potential presence of carbonatite.

\subsubsection{Metasomatism}

Carbonatite intrusions are typically accompanied by metasomatic aureoles of fenitized country rocks. Fenitization represents a variable, typically polyphase processes of alkali metasomatism progressively removing silica and producing alkali feldspars, commonly also alkali amphibole or aegirine, and occasionally nepheline; the overall character of fenitization may be sodic or potassic (Le Bas 2008 and references therein).

Potassic fenitization is commonly interpreted as being related with shallow carbonatite intrusions (see, e.g., Heinrich 1966; Gittins et al. 1975; Le Bas 2008). Zones of potassic fenitization are also frequently associated with brecciation (Le Bas 2008). The presence of carbonate minerals in metasomatic rocks is not necessary and many typical fenites highly dominated by alkali feldspar (albite or K-feldspar) do not contain any.

Kopecký (1988) mentioned finding a xenolith of carbonatized syenite fenite with relics of quartz replaced by carbonate in the DP-3 borehole. According to its character, such a xenolith could represent fenitized basement rock or clastic sediment from underneath the DHVC. However, no sample is available and no detailed documentation of the xenolith and its host-rock petrography has been published. No other fenitized xenolith has been identified among a number of basement xenoliths studied in the past decade.
The products of alkali metasomatic overprint on the alkaline igneous rocks are currently observable in the Doupov Intrusive Complex. Even though typical sodic metasomatism leading to albitization or the origin of Na-rich mafic minerals is definitely lacking at the present erosion level of the DIC, phlogopitization associated with brecciation of clinopyroxenites and some other rocks argues for the action of K-rich metasomatic fluids. This typically potassic metasomatism was pervasive; however, thin sections from the DB-2 drill-core document that it later changed to more channelized invasion of fluids producing essentially sodalite minerals accompanied by K-feldspar and minor apatite. The latter process closely preceded intrusions of innumerable veinlets of sodalite syenite and dykes of monzodiorite to sodalite monzosyenite.

An extreme result of strong pervasive phlogopitization is represented by the "pseudolamprophyre" that is spatially associated with olivine ijolite at the eastern margin of the DIC. Chemically, this "pseudolamprophyre" (DH1321) is similar to melteigite except for being even more mafic and particularly much higher in $\mathrm{K}$ but low in $\mathrm{Na}$. Incompatible trace elements also display a very similar pattern with consistently lower contents in "pseudolamprophyre". Rubidium and Cs, which are enriched similarly to $\mathrm{K}$, and also $\mathrm{Ba}$, which is enriched much less than $\mathrm{K}$, are the sole exceptions.

Although much less common than typical fenitization, extensive phlogopitization has been reported from many localities around the world for carbonatites that came into contact with highly mafic and ultramafic rocks (Heinrich 1966, 1970; Gittins et al. 1975; Le Bas 2008, and many others). Gittins et al. (1975) considered phlogopitization of pyroxenites to be a special type of fenitization.

Sodalite is not a very common and important mineral in fenites, although such cases do rarely exist, e.g. around ferrocarbonatite at Swartbooisdrif in Namibia (Thompson et al. 2002; Drüppel et al. 2005). However, those sodaliterich fenites have albite as the major mineral and the whole metasomatic alteration is typically sodic.

Pervasive phlogopitization together with the freshness of the phlogopite without any secondary alterations and the abundance of sodalite minerals in the DIC are noteworthy. The almost total absence of typical low-temperature minerals in phaneritic rocks including clinopyroxenite and heterogeneous breccias is a very interesting feature of the whole complex. The only exceptions are disseminated secondary carbonates partially replacing early sodalite minerals at the margins of the sodalite monzodiorite dykes and sodalite syenite veinlets, and also the presence of accessory epidote at the contacts, or in the close proximity, of these veins. Therefore, we assume that the fluids responsible for the origin of secondary phlogopite were high-temperature and of rather special composition. 
Hot fluids responsible for metasomatism at Doupov might not necessarily be related to any hidden carbonatite intrusion. Metasomatic, frequently potassic aureoles are also known around highly alkaline intrusions of ijolitic composition. The ijolitic-type fluids have relatively low $\mathrm{XCO}_{2}$, high activities of alkalis, $\mathrm{SiO}_{2}$ and $\mathrm{Al}_{2} \mathrm{O}_{3}$, and low activity of $\mathrm{CaO}$ (Morogan 1994), the characteristics compatible with origin of phlogopite in mafic rocks.

Ultimate resolution of the "carbonatite problem" in Doupov is, however, hardly possible without new drill hole(s) reaching significantly greater depths than those from the late sixties of the last century.

\section{Conclusions}

1. Phaneritic intrusive rocks from Doupov are more variable than those from the České středohoří Volcanic Complex. In addition to essexites, sodalite-bearing monzodiorites and sodalite monzosyenites with "wet" mineral assemblages, the Doupov Intrusive Complex also includes clinopyroxenites and highly undersaturated nephelinolites ranging from olivine melteigite to ijolite to rare urtite, predominantly with "dry" mineral assemblages.

2. As the phaneritic intrusive rocks $(\sim 30 \mathrm{Ma})$ are older than the overlying lava sequences, the Doupov Intrusive Complex provides proof for the polyphase evolution of the whole Doupovské hory Volcanic Complex.

3. The geochemical and isotopic data suggest that the less undersaturated "wet" essexitic rocks and the more undersaturated nephelinolites (melteigite-ijolite-urtite) with predominantly "dry" mineralogy evolved independently and their parental mafic magmas were derived from distinct mantle sources.

4. The melteigite-ijolite-urtite group is isotopically close to the "European Asthenospheric Reservoir" or the "Common Mantle Source".

5. Less undersaturated rocks display more pronounced lithospheric mantle source fingerprints. The sodalite monzosyenite may be also contaminated by rocks of the continental crust.

6. Fractional crystallization of both mafic groups was dominated by clinopyroxene with an increasing role of titanite and also apatite in the late stages. In contrast to sodalite syenite, the evolved urtite composition displays no indication of feldspar fractionation.

7. Clinopyroxenites may represent cumulates from both ijolitic and essexitic mafic magmas. Brecciation of clinopyroxenites and deformation of both clinopyroxene and phlogopite may be due to explosive release of hot magmatic fluids from an evolving deeper magma reservoir. Clinopyroxenite fragments were transported to a very shallow level and breccias were invaded by metasomatizing hot fluids and residual melts.

8. Some features of the Doupov Intrusive Centre (widespread brecciation, locally strong phlogopitization) are not contradictory to the former hypothesis assuming the presence of a carbonatite intrusion at depth, beneath the alkaline silicate intrusions. However, the source of metasomatizing fluids could have been the ijolitic magmas themselves.

Acknowledgements.This research was financially supported by the Grant Agency of the Academy of Sciences of the Czech Republic (Project No. IAA300130612 "Combined magnetostratigraphic studies of Cenozoic volcanics, Bohemian Massif"), the Ministry of Education, Youth and Sports of the Czech Republic (Research Plan No. MSM0021620855, Faculty of Science, Charles University in Prague), and the Ministry of the Environment of the Czech Republic (Research Plan MZP0002579801, Czech Geological Survey). The K-Ar analytical works were partly supported by the Hungarian National Scientific Foundation (OTKA No. K68153). P. Hradecký (Czech Geological Survey) is acknowledged for providing old thin sections from Flurbühl. We are greatly indebted to two anonymous reviewers for their constructive criticism that helped us to considerably improve the manuscript. The text also profited from a language check by M. Štulíková and the editorial work of V. Janoušek.

Electronic supplementary material. The GPS coordinates and a map of the sampling sites, mineral composition data for clinopyroxene, hornblende and biotite from the intrusive rocks, and a table documenting accuracy of the whole-rock analyses are available online at the Journal web site (http://dx.doi.org/10.3190/jgeosci.074).

\section{References}

Balogh K (1985) K/Ar Dating of Neogene Volcanic Activity in Hungary: Experimental Technique, Experiences and Methods of Chronologic Studies. ATOMKI Rep., D/1: 277-288

BAUER F (1903) Petrographische Untersuchung des Duppauer Theralithvorkommens. Zts Krist Mineral Petrogr 22: 266-296

BECKE F (1900) Vorläufige Mitteilung über die Auffindung von Theralith am Flurhübl bei Duppau. Verh K-kön geol Reichanst 13/14: 351-353

BogaARd PJF, WÖRner G (2003) Petrogenesis of basanitic to tholeiitic volcanic rocks from the Miocene Vogelsberg, Central Germany. J Petrol 44: 569-602

Boynton WV (1984) Cosmochemistry of the rare earth elements: meteorite studies. In: HENDERSON P (ed) Rare Earth 
Element Geochemistry. Developments in Geochemistry. Elsevier, Amsterdam-New York, pp 63-114

Cajz V, Vokurka K, Balogh K, Lang M, Ulrych J (1999) The České středohoří Mts.: volcanostratigraphy and geochemistry. Geolines 9: 21-28

CAJZ V, RAPPRich V, RadoŇ M (2006) Volcanics on the periphery of the Doupovské hory Mts. - a volcanological study of the Dětaň paleontological site. Zpr geol Výzk v R 2005: 13-16

Cebrià JM, Wilson M (1995) Cenozoic mafic magmatism in Western/Central Europe: a common European asthenospheric reservoir. Terra Nova Abstract Suppl 7: 162

David K, Schiano P, Allègre CJ (2000) Assessment of the $\mathrm{Zr} / \mathrm{Hf}$ fractionation in oceanic basalts and continental materials during petrogenetic processes. Earth Planet Sci Lett 178: 285-301

Dèzes P, Schmid SM, Ziegler PA (2004) Evolution of the European Cenozoic Rift System: interaction of the Alpine and Pyrenean orogens with their foreland lithosphere. Tectonophysics 389: 1-33

Downes H (2001) Formation and modification of the shallow sub-continental lithospheric mantle: a review of geochemical evidence from ultramafic xenolith suites and tectonically emplaced ultramafic massifs of Western and Central Europe. J Petrol 42: 233-250

DrÜPPEL K, HoEFs J, OKRUSCH M (2005) Fenitizing processes induced by ferrocarbonatite magmatism at Swartbooisdrif, NW Namibia. J Petrol 46: 377-406

Dupuy C, Liotard JM, Dostal J (1992) Zr/Hf fractionation in intraplate basaltic rocks: Carbonate metasomatism in the mantle source. Geochim Cosmochim Acta 56: 2411-2423

FeJfar O, Kaiser TM (2005) Insect bone-modification and paleoecology of Oligocene mammal-bearing sites in the Doupov Mountains, northwestern Bohemia. Palaeon Electron 8.1.8A: 1-11, http://palaeo-electronica. org/2005_1/fejfar8/fejfar8.pdf

Fujinawa A, Green TH (1997) Partitioning behaviour of Hf and $\mathrm{Zr}$ between amphibole, clinopyroxene, garnet and silicate melts at high pressure. Eur J Mineral 9: 379-391

Gittins J, Allen CR, CoOper AF (1975) Phlogopitization of pyroxenite; its bearing on the composition of carbonatite magmas. Geol Mag 112: 503-507

Green TH, Pearson NJ (1986) Rare-earth element partitioning between sphene and coexisting silicate liquid at high pressure and temperature. Chem Geol 55: 105-119

Haloda J, Rapprich V. Holub FV, Halodová P, Vaculovič $\mathrm{T}$ (2010) Crystallization history of ijolitic rocks from the Doupovské hory Volcanic Complex (Oligocene, Czech Republic). J Geosci 55: 279-297

Hart SR, Dunn T (1993) Experimental Cpx/melt partitioning of 24 trace elements. Contrib Mineral Petrol 113: 1-8

HeinRICh EWM (1966) The Geology of Carbonatite. Rand McNally \& Co, Chicago, pp 1-555
HeInRICH EWM (1970) The Palabora carbonatitic complex; a unique copper deposit. Canad Mineral 10: 585-598

HiBsCh JE (1899) Geologische Karte des Böhmischen Mittelgebirges, Blatt II (Rongstock - Bodenbach). Alfred Hölder, Wien, pp 1-101

НiBSCH JE (1902) Über Sodalithaugitsyenit im Böhmischen Mittelgebirge und über die Beziehungen zwischen diesem Gestein und dem Essexit. Tschermaks Mineral Petrogr Mitt 21: 157-170

Hradecký P (1997) The Doupov Mountains. In: VRÁna S, ŠTĚDRÁ V (eds) Geological Model of Western Bohemia Related to the KTB Borehole in Germany. Sbor geol Věd, Geol 47: 125-127

JANOUŠEK V, FARROW CM, ERBAN V (2006) Interpretation of whole-rock geochemical data in igneous geochemistry: introducing Geochemical Data Toolkit (GCDkit). J Petrol 47: $1255-1259$

KeLler J (1981) Carbonatitic volcanism in the Kaiserstuhl alkaline complex: evidence for highly fluid carbonatitic melts at the Earth's surface. J Volcanol Geotherm Res 9: 423-431

KoPECKÝ L (1966) The find of fenites and alkaline rocks in the České středohoří Mts. Věst Ústř Úst geol 41: 121-124 (in Czech, English abstract)

KoPECKÝ L (1987) The Roztoky pseudotrachyte caldera in the České středohoří Mts., Czechoslovakia. In KoPECKÝ L (ed) Proceedings of the First Seminar on Carbonatites and Alkaline Rocks of the Bohemian Massif and Ambient Regions. Geological Survey, Prague, pp 119-156

KopeCKÝ L (1987-88) Young volcanism of the Bohemian Massif. Geol Hydrometal Uranu, 11(3): 30-67; 11(4): $3-44 ; 12(1): 3-40 ; 12(2): 3-56 ; 12(3): 3-40 ; 12(4)$ : 3-40 (in Czech)

KopeckÝ L (1988) Young volcanism of the Bohemian Massif, Part 3. Geol Hydrometal Uranu 12(3): 3-40 (in Czech)

Kopecký L (2010) České Středohoří Mts. and Ambient Young Alkaline Volcanic Complexes in the Ohre Rift, Czech Republic: Volcanology, Petrology and Rift Evolution. Czech Geological Survey, Prague, pp 1-188

KopeckÝ L, Dobeš M, Fiala J, ŠŤOvíčKová N (1970) Fenites of the Bohemian Massif and the relations between fenitization, alkaline volcanism and deep fault tectonics. Sbor geol Věd, Geol 16: 51-112

LE BAS MJ (2008) Fenites associated with carbonatites. Canad Mineral 46: 915-932

Le Maitre RW (ed), Streckeisen A, Zanettin B, Le Bas MJ, Bonin B, Bateman P, Bellieni G, Dudek A, Efremova S, Keller J, Lameyre J, Sabine PA, Schmid R, Sørensen H, Wooley AR (2002) Igneous Rocks. A Classification and Glossary of Terms. Recommendations of the International Union of Geological Sciences Subcommission on the Systematics of Igneous Rocks. $2^{\text {nd }}$ Edition, Cambridge University Press, Cambridge-New York, pp 1-193 
Lemarchand F, Villemant B, Calas G (1987) Trace element distribution coefficients in alkaline series. Geochim Cosmochim Acta 51: 1071-1081

Lustrino M, WiLSON M (2007) The circum-Mediterranean anorogenic Cenozoic igneous province. Earth Sci Rev 81: $1-65$

Míková J, Denková P (2007) Modified chromatographic separation scheme for $\mathrm{Sr}$ and $\mathrm{Nd}$ isotope analysis in geological silicate samples. J Geosci 52: 221-226

MцČOCH B (2003) Character of the contact between the Saxothuringian and Teplá-Barrandian Unit. Geolines 16: 75

MLČOCH B (2006) Ultrabasic rocks of the basement below the Tertiary volcanites of the Doupovské hory Mts. Zpr geol výzk v R 2005: 25-26 (in Czech)

MlČOCh B, KonopÁSeK J (2010) Pre-Late Carboniferous geology along the contact of the Saxothuringian and Teplá-Barrandian zones in the area covered by younger sediments and volcanics (western Bohemian Massif, Czech Republic). J Geosci 55: 81-94

MOROGAN V (1994) Ijolite versus carbonatite as sources of fenitization. Terra Nova 6: 166-176

Odin GS (1982) Numerical Dating in Stratigraphy. John Wiley and Sons, New York, pp 1-1040

Pfeiffer L, Wenzel T, Eckstein L (1990) Neue Alterswerte vom Oberwiesenthaler Eruptivstock im Westerzgebirge und ihre geologischen Konsequenzen. Freiberg Forsch H C 441: 115-119

RAPPRICH V (2003) Analcimized leucites and Ti-phlogopite from Doupovské hory Mts. Zpr geol Výzk v R 2002: 180-181 (in Czech, English abstract)

RAPPRICH V (2005) Compositional variation of clinopyroxenes of basaltic, essexitic and tephriphonolitic rocks from the Doupovské hory Volcanic Complex, NW Bohemia. J Czech Geol Soc 50: 119-132

Rapprich V, Holub FV (2008) Geochemical variations within the Upper Oligocene-Lower Miocene lava succession of Úhošt' Hill (NE margin of Doupovské hory Mts., Czech Republic). Geol Quart 52: 253-268

ShrBenÝ O (1982) Chemistry of alkaline volcanic rocks of the Doupovské hory Mts., Bohemia. Čas Mineral Geol 27: $139-158$

Steiger RH, Jäger E (1977) Subcommission on Geochronology: convention on the use of decay constants in geo- and cosmochronology. Earth Planet Sci Lett 36: 359-362

Sun SS, McDonough WF (1989) Chemical and isotopic systematics of oceanic basalts; implications for mantle composition and processes. In: SAUnders AD, Norry MJ (eds) Magmatism in the Ocean Basins. Geological Society of London Special Publications 42: 313-345

ŠantrưČek P, Bưžek Č, Kopecký L, Malecha A, VÁcl J (1967) Tertiary Basins and Young Volcanics of the Bohemian Massif. International Geological Congress,
XXIII Session Prague 1968, Guide to Excursion 13 AC, pp 1-53

Thompson RN, Smith PM, Gibson SA, Mattey DP, Dickin AP (2002) Ankerite carbonatite from Swartbooisdrif, Namibia: the first evidence for magmatic ferrocarbonatite. Contrib Mineral Petrol 143: 377-395

Tiepolo M, Oberti R, Vannucci R (2002) Trace-element incorporation in titanite: constraints from experimentally determined solid/liquid partition coefficients. Chem Geol 191: 105-119

ULRYCH J (1998) Geochemistry of subvolcanic alkaline rock series of the Roztoky Intrusive Centre, České středohoři Mts., Bohemia. Erlanger Beitr Petr Min 8: 1-42

Ulrych J, Balogh K (2000) Roztoky Intrusive Centre in the České středohoří Mts.: differentiation, emplacement, distribution, orientation and age of dyke series. Geol Carpath 51: 383-397

Ulrych J, Pivec E, Fiala J, Lang M (1983) Petrology of the alkaline subvolcanic rocks from the Roztoky area (České středohoří Mts.). Rozpravy ČSAV, Ř mat prír Věd 93 (8): 1-85

Ulrych J, Svobodová J, Balogh K (2002) The source of Cenozoic volcanism in the České středohoří Mts., Bohemian Massif. Neu Jb Mineral, Abh 177: 133-162

Ulrych J, Lloyd FE, Balogh K (2003) Age relations and geochemical constraints of Cenozoic alkaline volcanic series in W Bohemia: a review. Geolines 15: 168-180

Ulrych J, Lloyd F E, Balogh K, Hegner E, Langrová A, Lang M, Novák J K, ŘAnda Z (2005) Petrogenesis of alkali pyroxenite and ijolite xenoliths from the Tertiary Loučná-Oberwiesenthal Volcanic Centre, Bohemian Massif in the light of new mineralogical, geochemical, and isotopic data. Neu Jb Mineral, Abh 182: 57-79

Ulrych J, Nižňñanský D, Pertlik F, Giester G, Ertl A, BRANDSTÄTter F (2006) Clinopyroxene from an alkali pyroxenite xenolith, Loučná-Oberwiesenthal Volcanic Centre, Bohemian Massif: crystal chemistry and structure. Geol Quart 50: 257-264

VoKURKa K (1997) Neodymium and strontium isotopes of basalts from the Doupovské hory Mts. (Bohemia). J Czech Geol Soc 42: 17

Wiesbaur JB (1901) Theralith im Duppauer Gebirge. Lotos 21: $62-71$

Wilson M, Downes H (1991) Tertiary-Quaternary extension-related alkaline magmatism in Western and Central Europe. J Petrol 32: 811-849

Wilson M, Downes H (2006) Tertiary-Quaternary intraplate magmatism in Europe and its relationship to mantle dynamics. In: Gee DG, Stephenson RA (eds) European Lithosphere Dynamics. Geological Society London Memoirs 32: 147-166

WimMENAUER W (1974) The alkaline province of Central Europe and France. In: Sørensen H (ed) The Alkaline Rocks. Wiley, London, pp 238-271 
Wooley AR (2003) Igneous silicate rocks associated with carbonatites: their diversity, relative abundances, and implications for carbonatite petrogenesis. Periodico Mineral 72: 9-17

Wooley AR, KJarsgaArd BA (2008) Paragenetic types of carbonatite as indicated by the diversity and relative abundances of associated silicate rocks: evidence from a global database. Canad Mineral 46: 741-752

ZARTNER WR (1938) Geologie des Duppauer Gebirges. I. Nördliche Hälfte. Abh Dtsch Akad Wiss Kunste, matnaturwiss Abt 2: 1-132

Zindler A, Hart SR (1986) Chemical geodynamics. Ann Rev Earth Planet Sci 14: 493-571 